\title{
Social Capital in Europe. A Three-Step Analysis. Its Structure, Levels, Individual and Contextual Determinants
}

\author{
Conceição Pequito Teixeira
}

Political Science Department, Higher Institute for Social and Political Sciences (ISCSP-UTL) spequito2012@hotmail.com

\section{Doi:10.5901/mjss.2013.v4n9p356}

\section{Abstract}

Despite its historical roots and wide contemporary use, the debate over the conceptualization of social capital is very much alive among researchers of different academic subjects, with its main goal being the development of empirical measurement tools. The chief aim of this article is to demonstrate the multidimensional and consistent structure of social capital in European regions through an exploratory factor analysis and a subsequent confirmatory factor analysis. Throughout the paper we critically analyze the gap between the theoretical understandings of social capital and the ways it has been measured in most empirical work so far. We use data from the five European Social Survey waves (2002-2010) in European regions. We also approach social capital levels in these regions: diachronically between 2002 and 2010 using a time-series analysis and synchronically in 2010 using an analysis of variance to determine mean differences (ANOVA). Lastly, we study the effect several determinants have, at individual and national levels over the different dimensions of social capital so as to determine whether there are verifiable differences between European regions. In order to do this we used OLS regression analyses.

Keywords: Social Capital Definition; Social Capital Individual-Level Determinants; Social Capital Contextual-Level Determinants; Levels of Social Capital; Europe

\section{Introduction}

Over the past 20 years, the academic interest in studying the social capital met a huge growth among sociologists, political scientists and economists (Svendsen and Svendsen, 2009). However, there is not a single consensus definition of social capital, assuming this category sometimes "rain hat" or even "catch-all" (Grootaert and Bastelaer, 2000; Lin et al., 2001).

The aim of this article was to identify the similarities and differences between European regions concerning the structure, levels and determinants of social capital. The actuality of the topic is related to the growing awareness of the importance of social context and intangible assets in the process of democratic institutional process. The present article was composed of three major sections. First, there was presented the review literature about the historical origins and theoretical approaches to the social capital concept, noting in particular its multidimensional nature, and its main components.

The second section comprised the comparative research on the structure of social capital in the European regions, through the application, first to exploratory factor analysis, and then, in the confirmatory factor analysis. This comparative, consistent and integrated framework constitutes an important step towards to developing the comparative analysis across regions and countries in which social capital concerns. Based on alternative theoretical approaches, the components of social capital will be described alongside structural and cognitive dimensions.

Subsequently, the individual determinants of social capital in European regions will be discussed. Political science is related to the notion that such a complicated concept should be studied in a wider context where social capital accumulates, appears and operates. Thus, although the determinants and sources of social capital are studied mainly at the individual level not considering national level determinants. In this analysis, we assume that "the context makes a difference".

The individual determinants of social capital can be divided into two groups. The first group includes a wide range of psychological and cultural and socio-economic characteristics of individuals, such as personal income and education, family and social status, values and personal experiences, which determine the incentive of individuals to invest in social capital. The second group of social capital determinants includes contextual or systemic factors at the level of the region, such as the overall level of development, democracy's longevity, quality and fairness of formal institutions, human 
development, distribution of resources and society's communications modernization, etc.

From our point of view, the main shortcoming of previous empirical studies lies in the fact that they include incomplete set of social capital dimensions (mostly, only indicators of general trust and/or membership in voluntary organisations are included) and a limited number of their determinants. Also, the data sources and list of regions or countries analysed by different authors are not similar, making comparisons and generalisation of the (often varying) results problematic.

\section{Definition and Theoretical Approaches to Social Capital}

Although, the concept of social capital is a concept so influential today, it is far from a new concept or even original. If it is true that belongs to Robert Putnam, with the publication of his work, Making Democracy Work: Civic Traditions in Modern Italy, 1993 (with Robert Leonardi and co-authored by Raffaela Nanneti), the merit of having recovered and especially popularized this concept, the fact is that it dates back to the nineteenth century and has as main inspiring the French political thinker Alexis de Tocqueville, and one that was surely his masterpiece Democracy in America, published in two volumes.

Still, on the roots of the concept of social capital, and about the fact that this is not a new concept and not all original, it must be said that in the twentieth century, the first and systematic development of the concept of social capital is owned by two sociologists, a Frenchman, Bourdieu (1984, 1985), and an American, Coleman (1986, 1990), both centred on individuals or small groups as the units of analysis.

But that the capital is not a new concept, with Putnam it gained new dimensions and horizons. Following here over Coleman than Bourdieu, Putnam was the first theoretical way but also empirical, social capital as a "public good", not limited to defining it just as such. At the individual level, social capital has been seen as a resource embedded in the social structure, which is useful for achieving higher reputation, power and material welfare. At the national level, social capital in the form of networks now constitutes a powerful information channel, while trust and norms can help to discourage opportunistic behaviour in the presence of risk and uncertainty.

If we are to realize the implications of this new approach is necessary to understand the way that Robert Putnam in Making Democracies Work (1993) and Bowling Alone (2000) linking the ideas of social capital to the importance of civic associations and voluntary organizations for political participation and effective governance, and strong influence on him was the work of Alexis de Tocqueville, Democracy in America. In fact, most accounts of Putnam's social capital rely predominantly on the importance of social interactions and voluntary associations in the manner originally suggested by Tocqueville.

In Making Democracy Work (1993), Putnam sustains that participation in political and social activities and collective organizations is the primary means of civic engagement. The author claims that individuals' participation in social and political organizations "instils in their members habits of economic cooperation, solidarity, and public spiritedness" (Putnam, 1993: 89-90).

From an economist's point of view, cooperation and information sharing are facilitated when individuals have the opportunity to interact within organizations. It is obvious to Putnam that voluntary organizations are seen as creators of social capital because of their socialization effects on reciprocity and cooperative values and norms. Associations function as "learning schools for democracy." The claim is that in areas with stronger, dense, horizontal, and more crosscutting social networks there is a spill over from membership in organizations to the cooperative values and norms that citizens develop. In areas where networks with such characteristics do not develop, there are fewer opportunities to learn "civic virtues" and "democratic attitudes", resulting in a lack of trust and values and civic pride.

It is not just a matter of faith or philosophic, since his seminal work (1993) proves it empirically, or at least so he judges. To study the regional differences in Italy, he and their colleagues found that large variations in the effectiveness of Italy's regional governments were explained not by their resources or structures, but by regional differences in social capital. Robert Putnam defined these as features of social life networks, norms, and trust that enable participants to act together more effectively to pursue shared objectives. Social capital, in short, refers to connections and the attendant social norms and trust (Putnam, 1995).

About Putnam's work much more would be to say, but what interested us point out was the more distanced of the classics played by Robert Putnam and by contemporary authors and that allows us to distinguish social capital with a single attribute (micro) and the issued share capital as a collective (macro) attribute. Basically, two main approaches can be discerned in the analysis of social capital in terms of focus and its outcomes.

At individual-level to social capital can be seen as the direct result of investment by actors, who have the aim of 
receiving a return on their investment. Individuals assume deliberately to invest their time and money in social capital with expected future returns in the form of material (micro-level approach).. At the level of nations and regions, the main concern is related to the formal institutions - their trustworthiness, quality and ability to assure social cohesion (macrolevel approach). However, these opposite perspectives of social capital can be taken to be complementary rather than found against, each offering a different outlook of the concept, related to specific research subjects and problems which could be solved with the help of social capital.

It follows another dichotomy very usual in the specialized literature that studies the social capital. If in the first case, it is the primacy given to the structural elements of social capital that facilitate social interaction, that is social networks, both formal and informal. In the second, has sought to highlight the cultural and cognitive elements of social capital, including different types of trust and civic norms, also referred to as trustworthiness.

\title{
3. Methodology: Data Sources and Measurement Issues
}

The following empirical analysis compares the structure, the levels, the individual, and contextual determinants of social capital in six European regions. The analysed regions are: 1) Northern Europe (Denmark, Finland, Norway and Sweden); 2) Western and Central Europe (Austria, Belgium, France, Germany, Netherlands and Switzerland); 3) Britain and Ireland; 4) Southern Europe (Greece, Spain and Portugal); 5) Eastern Europe (Czech Republic, Hungary, Poland, Slovakia and Slovenia); and 6) Baltic countries (Estonia and Lithuania).

We used data from the five European Social Survey (ESS) waves. The ESS is a biennial multi-country survey that covers over 30 countries. The first round was fielded in 2002/2003, the fifth in 2010/2011.

\section{Social capital: A multidimensional concept and its operationalization}

\section{1 - At long last... What are the components of social capital?}

So far, it is consensual that social capital is a particularly complex and problematic concept due to its multidimensional nature (Dasgupta and Serageldin, 2000; Parts, 2009). It can be divided into two parts: the structural aspect, which includes participation in formal and informal networks and facilitates social interaction (Uphoff, 2000), and the cognitive aspect, which predisposes people to act in a socially beneficial and constructive way and refers to shared norms, values, trust, attitudes and beliefs (Hjøllund and Svendsen, 2000; Parts, 2009).

If we adopted Putnam's definition of social capital $(1993,2000)$, we would easily identify its components and integrate them in structural and cognitive aspects. This is how he introduces the idea in its most extensive and complex form in Bowling Alone (2000)

\begin{abstract}
Whereas physical capital refers to physical objects and human capital refers to the properties of individuals, social capital refers to connections among individuals - social networks and the norms of reciprocity and trustworthiness that arise from them. In that sense social capital is closely related to what some have called "civic virtue". The difference is that "social capital" calls attention to the fact that civic virtue is most powerful when embedded in a sense network of reciprocal social relations. A society of many virtuous but isolated individuals is not necessarily rich in social capital. In other words, interaction enables people to build communities, to commit themselves to each other, and to knit the social fabric. A sense of belonging and the concrete experience of social networks (and the relationships of trust and tolerance that can be involved) can, it is argued, bring great benefits to people (Putnam, 2000: 19)
\end{abstract}

While in Making Democracy Work (1993) he propelled the issue of social capital to the front stage of the social sciences, Putnam also established here, in very simple terms, what was new and original about the concept, its components and how to operationalize them empirically. According to Putnam (1993), social capital includes 'the features of social organization, such as networks, social norms and trust, that can improve the efficiency of society by facilitating coordinated action' (Putnam, 1993: 167).

Social norms and networks 'provide defined rules and sanctions for individual participation in organizations' (Putnam, 1993: 166), and promote reciprocity and cooperation 'founded on a lively sense of mutual value to the participants of such cooperation, not a general ethic of the unity of all men or an organic view of society' (Putnam, 1993:168). On the whole, networks and norms provide for such an internal mutual commitment a mechanism that 'rational individuals will transcend collective dilemmas' (Putnam, 1993: 167).

From here it is easy to conclude that among the structural elements of social capital we find social networks, from 
where its cognitive and cultural elements are generated. Furthermore, and following Putnam closely, we have three social capital components: 1) social networks; 2) social norms (among which are reciprocity and cooperation norms); and 3 ) trust. What we will do next is empirically prove the multidimensional nature of social capital. However, we will steer away from Putnam's definition and operationalization a little. In order to do so, we will present social capital's various components in a more deep manner. We will add some components to Putnam's concept, in agreement with our reading of what social capital is in European contemporary societies and with how we will operationalize it.

\subsection{What does specialized literature teach us?}

\subsubsection{Social networks individual determinants}

In the fifth round of the ESS (2010), the participation in informal social networks is measured by the survey questions that ask people 'How often do you meet socially with friends, relatives or work colleagues?' 'Compared to other people of your age, how often would you say you take part in social activities?' and 'How important do you think it is to be loyal to your friends and devote yourself to people who are close?' The ESS contains two survey questions that can be used to measure the participation in formal social networks. People are asked 'Are you or have you ever been a member of a trade union or similar organization? If yes, is that currently or previously?' and 'during the last 12 months have you participate in an organization or association?

\subsubsection{Social and institutional trust individual determinants}

Trust and trustworthiness are integral elements of reciprocity. An individual who abides by the norm of reciprocity is trustworthy. The information regarding the trustworthiness of others is an essential input to the reciprocal decision of an individual whether or not to cooperate. As Putnam (2000) puts it, 'I'll do this for you now, without expecting anything immediately in return, and perhaps down the road you or someone else will return the favor (...) A society that relies on generalized trust is more efficient than a distrustful society, for the same reason that money is more efficient than barter' (Putnam, 2000: 134-5).

Here we also chose a different measure of generalized trust. We decided to use three survey questions from the ESS and build an index that allowed us to measure it: 1) Generally speaking, would you say that most people can be trusted, or that you can't be too careful in dealing with people? 2) Do you think that most people would try to take advantage of you if they got the chance, or would they try to be fair? 3) Would you say that most of the time people try to be helpful or that they are mostly looking out for themselves? This four-item scale can be considered reliable, with a Cronbach's alpha of 0.860

Concerning institutional trust, we must make a distinction between (1) confidence in institutions on the representation side of the political system (parties and parliaments) and (2) confidence in institutions on the implementation side (government and legal system). The ESS contains questions that can be used to measure these national political institutions. In the questionnaire we can read: please tell me on a score of 0-10 how much you personally trust each of the institutions I read out. 0 means you do not trust an institution at all, and 10 means you have complete trust: 1) [country]'s parliament?, 2) the government; 3) the legal system; and 4) political parties.

\subsubsection{Civic norms and political awareness}

Social norms often facilitate more predictable or beneficial behaviour patterns of individuals. In fact, it is hard to imagine how interaction and exchange between strangers could take place without norms. According to Putnam, 'reciprocity' is clearly the underpinning norm amongst social norms, which is strongly reflected by the ethics of 'do unto others as you would have them do unto you'. While the direct exchange of 'favors' can be seen as a form of transaction that requires no motivation other than narrow self-interest, the supply of generalized reciprocity is increased by making 'expected behaviour' something required by a social norm. Reciprocity is made up of a series of acts, each of which is altruistic in the short run (benefiting others at a cost to the altruist), but together they usually make every participant better off (Taylor, 1982; quoted in Putnam, 2000: 134).

The ESS questions we found most fit to measure this component divide into two distinct blocks. The first asks respondents whether they consider it important 'to do what is told and follow rules'; 'to behave properly'; 'to help people for the well-being of others' and 'to understand different people'. In the second block, we tried to measure the 
respondents' degree of perception regarding political issues, which often contribute to changing social norms that are in effect or, at least, their understanding by society members.

To that purpose, we used an ordinal recurrent question in all surveys and, therefore, also in the ESS: 'Please indicate your degree of interest in politics'. To this we added an index (with Cronbach's a above .950) formed by the answers to the following questions: 'On an average weekday, how much of your time watching television is spent watching the news or programmes about politics and current affairs?'; 'On an average weekday, how much of your time listening to the radio is spent listening to the news or programmes about politics and current affairs?' and 'On an average weekday, how much time do you spend reading about politics and current affairs in the newspapers?'

\subsubsection{Social cohesion and sense of community individual determinants}

Although Putnam $(1993,2000)$ does not refer to it explicitly in his work, we consider social cohesion to be a cultural aspect intrinsic to the concept of social capital today. We find different definitions of a multicultural society in existent literature on the subject. One points to the existence of distinct ethnic communities, generated by voluntary or forced immigration and marked by differences in terms of language and/or religion and/or customs. Therefore, even European societies that were seen as non-multicultural now are, due to recent massive immigration.

The phenomenon of immigration is perhaps the greatest challenge. Today more than five percent of the resident EU population is non-EU Member State nationals. Multiculturalism is present in almost all the countries of the EU. Therefore, since societies of today are increasingly characterized as multicultural societies (Masini, 2011; Myria, 2005) inclusiveness and collective action depend on how they deal with ethnocentrism.

We used the following ESS questions to measure this last component of social capital. We also created a threeitem scale that can be considered reliable (Cronbach's alpha equals .920). The survey questions were: 1) Would you say it is generally bad or good for [country]'s economy that people from other countries come to live here? 2) Would you say that [country]'s cultural life is generally undermined or enriched by people coming from other countries to live here? 3) Is [country] made a worse or better place to live by people coming from other countries to live here?

\section{Research Propositions and Empirical Analysis}

Now that we laid out the structural and cultural/cognitive components of social capital, there are still some needful considerations before presenting the propositions for empirical analysis. The first group of propositions will be set up to identify the components and structure of social capital in European regions.

The basic assumption in this first group is that social capital is theoretically a multidimensional concept and not empirically a dependent variable resulting from an index or a scale but a stable and a multifaceted construct, i.e., the relative importance of alternative social capital components may differ by European regions with different overall economic and political development levels. Thus, the following proposition is exploratory in nature and suggests that:

P1a: The components of social capital are similar and unchangeable in European regions.

Based on empirical evidence, several scholars have pointed out that the levels of social capital in European regions are very different, especially amongst those that comprise transition countries, where levels are lower than in regions that include non-transition countries (Paldam and Svendsen, 2002). We will test this statement on the broad basis of social capital's components. Therefore, it could be expected that the data from the ESS also confirm the following proposition:

P1b: Although social capital structure is the same in European regions, its levels may differ both diachronically and synchronically.

The second group of propositions concerns the possible similarities and differences in the micro- and macro-level determinants of social capital between European regions. Given that social capital consists of separate components, it can be suggested that its sources also differ on these components. There are also some indicators (like civic and political awareness and social cohesion) that were not analysed in previous empirical studies. Thus, the current analysis of the determinants of social capital components is largely exploratory, and no precise proposition can be put forward for all components separately.

As Uslaner (2003) noted, there might be differences in social capital between European regions that are related to psychological, attitudinal or cultural factors, such as prior life experience and its interpretations. Based on this reasoning, we set up the following propositions:

P2a: Individual-level determinants are expected to have different effects (e.g. in the direction and magnitude) on 
social capital components in European regions.

We will now consider the last propositions. Social capital is also influenced by macro-level or contextual factors. Broadening the range of possible determinants is important because individuals do not live in isolation, but are part of a certain culture - so it is very likely that these national cultures have an impact on individual levels of social capital, such as the quality of institutions, income distribution, educational system, and the welfare state (rainmaker effect hypothesis).

Given that both micro-level and macro-level factors play a role in determining the levels of social capital, the question arises as to whether it is possible to list these determinants according to their relative importance. Thus, we arrived at the following general propositions:

P2b: The relative importance of micro- and macro-level factors might be different in European regions, in the case of different social capital components.

We used different statistical methods, applicable for cross-national datasets, to test the validity of our propositions in different stages of the research. In the first group, we used a factor analysis with principal components and a confirmatory factor analysis on pooled data in order to obtain latent factors of social capital (P1a). After, we used a descriptive analysis (ANOVA and t-test for mean comparisons) to compare the levels of social capital and time-series analysis to study measurements (equally) spaced over time (P1b).

In the second group we used OLS regression analysis to test the validity of P2a proposition. Finally, we used a multilevel analysis, since the main objective is to demonstrate the influence of social context on individual attitudes. The theoretical and technical requirements of regression multilevel models satisfy this requirement (P2b)

In order to test the validity of the multidimensionality of social capital, and before we move on to the statistical analysis, we will summarize the dimensions (or components) and their indicators.

Table 1. Dimensions of the concept of social capital

\begin{tabular}{|c|c|}
\hline $\begin{array}{l}\text { Dimensions or Components of Social } \\
\text { Capita } \\
\text { 1. Social Networks }\end{array}$ & Indicators \\
\hline \multirow{2}{*}{ - Informal social networks } & How often socially meet friends, relatives or colleagues \\
\hline & Take part in social activities compared to athers of same age \\
\hline \multirow[t]{2}{*}{ - Fomal social networks } & Mem ber of trace union or a similar organization \\
\hline & Worked as volurtary in an organizztion or association \\
\hline \multicolumn{2}{|l|}{ 2. Social and Inatitutional Truat } \\
\hline \multirow[t]{2}{*}{ - Generalized or 5ocia Trust } & $\begin{array}{l}\text { Most people can be trusted or you cannot be too careful } \\
\text { Most people try to take advartage of you, or try to be fair } \\
\text { Most of the time people are helpfu, or most ylooking for } \\
\text { themselves }\end{array}$ \\
\hline & Trust in countrys pariament \\
\hline \multirow{3}{*}{ - Institutional Trust } & Trust in poifical parties \\
\hline & Thust in the justice system \\
\hline & Trust in the policing system \\
\hline \multicolumn{2}{|l|}{ 3. Civic and Political Awareness } \\
\hline \multirow{4}{*}{ - Civic Norms } & Important to do what is told and follow rules \\
\hline & Important to behave properly \\
\hline & Important to understand differert people \\
\hline & Important to help people and care for the vell-being of ahers \\
\hline \multirow{3}{*}{ - Poitical Issues } & $\begin{array}{l}\text { Interest in poitics } \\
\text { Waching news/poibcsicurrert affairs on TV }\end{array}$ \\
\hline & Listering news/politics/current affairs on the radio \\
\hline & $\begin{array}{l}\text { Reading news/poitics/current affairs in the newspaper } \\
\text { Immigration is good for courtry's economy }\end{array}$ \\
\hline \multirow{2}{*}{ 4. Social Cohesion and Senre of Community } & Country's curtural life is enriched by immigrants \\
\hline & Immigrants make country a better place to live \\
\hline
\end{tabular}

According to theoretical literature, its dimensions rather than individual variables could better characterize the concept of social capital. In order to capture all the information from the above 22 individual social capital indicators into smaller number of variables, latent variables were constructed for each selected dimension. To test the empirical validity of the multidimensionality of social capital, an exploratory factor analysis was used. If each of the various dimensions (or components) of social capital captures specific aspects of the concept, the initial indicators chosen to describe a particular dimension or component should load to the same factor.

In order to test the similarities and differences of the social capital structure in European regions, the following 
analysis is performed on pooled data $(\mathrm{N}=38.974)$. The first-order exploratory factor analysis was conducted using the principal components method with varimax rotation (see Appendix A). To decide the number of factors, first, the Kaiser criterion was used: only the factors with eigenvalue greater than 1 were retained. Bartlett's Test of Sphericity is significant; the KMO test statistic is .0827 , which shows that the factor solution is good and stable.

Altogether, the extracted seven factors explain $59.84 \%$ of the total variance of 22 initial indicators included in the analysis (see Appendix A). The results also show that the indicators of social capital clearly divided into groups describing the predefined first-order components of social capital and every indicator corresponds to the dimension expected, which this indicator was assumed to measure. The factor loadings of indicators in factors, which they were chosen for, range from $5.6 \%$ to $12.5 \%$.

The structure of social capital components would be further clarified by second-order factor analysis, using initiallyobtained individual factor scores as inputs. This approach enables the validation of the measurement model of social capital, showing whether empirical data confirms the theoretically-derived structure of social capital, as presented earlier (see Appendix A).

The second-order exploratory factor analysis was conducted using the principal components method with varimax rotation with Kaiser Normalization on pooled data. Bartlett's Test of Sphericity is significant and the KMO test statistic is slightly higher at .600, which shows that the factor solution is fair and relatively stable. Altogether, the extracted four factors explain $57.1 \%$ of the total variance. All the four factors have a similar variance explained, $14.3 \%$, that shows the equilibrium in the variability the pooled data in second-order exploratory factor analysis (see Appendix A).

in contrast to exploratory factor analysis where all loadings are free to vary, CFA allows for the explicit constraint of certain loadings to be zero. Therefore, to validate definitely the proposition P1a, we had conducted this type of analysis too. As confirmatory analysis gives the factors that can be correlated to each other, these factors are next used as input in the second-order confirmatory factor analysis. This enables the structure and aggregation possibilities of social capital indicators to be further clarified as we can see in Figure 1 on global model of confirmatory analysis.

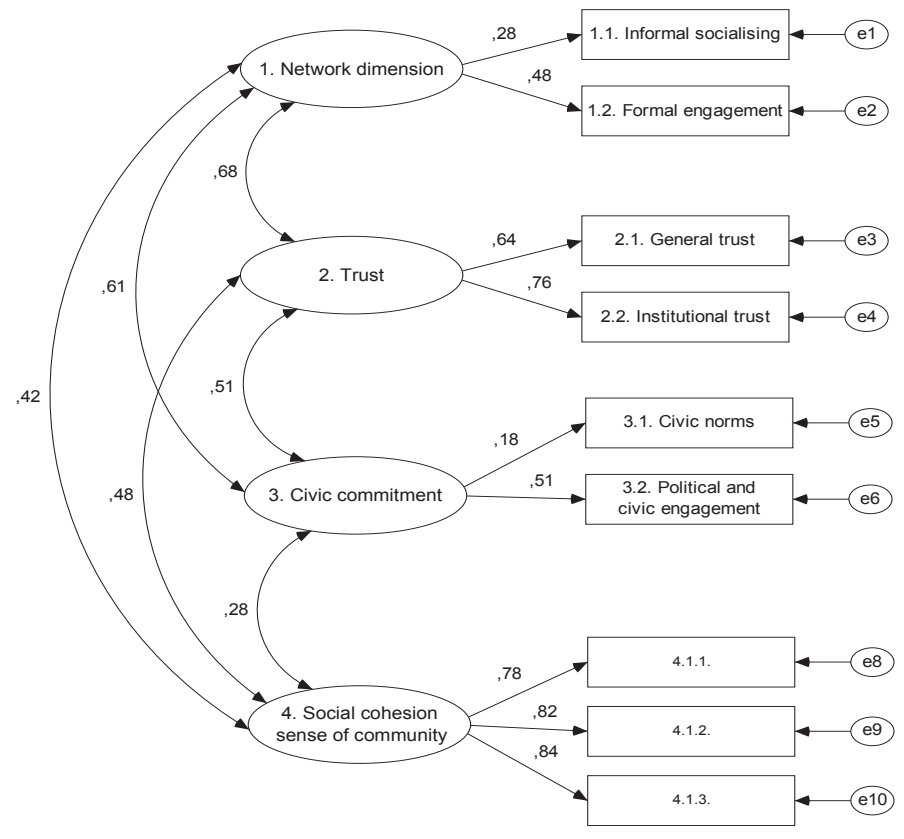

Figure 1. Confirmatory Factorial Analysis Model

There is convergent validity for all dimensions: the loadings are high $(M>0.500)$ and significant $(p<0.001)$; and the internal reliability is verified by the composite reliability (higher than 0.7 ), and the extracted variance is higher than 0.5 for most dimensions. On the other hand, it should be noted that all dimensions show significant correlations, which strengthens the use of first-order factors Finally, that measurements indicate a good fit, according to $\mathrm{CFI}(\mathrm{CFI}>0.90)$, RMSEA (RMSEA $<0.08)$ and NFI (NFI > 0.80), but not according to Chi-square $(p<0.05)$, this being value affected by the large sample dimension and $\mathrm{CFI}(\mathrm{CFI}<0.90)$. 
At this point, we can conclude by the validity not only theoretical but also empirical evidence of our first proposition (P1a). Yes, the proposition that the concept of social capital is not uniform but multidimensional is empirically valid, and it is in all European regions. What is more, its components are identical in all regions of Europe, i.e., the social capital has a structure or composition unchanging and constant in the European regional context.

\section{Levels and Trends of Social Capital in European Regions}

If the structure of the concept of social capital is similar and invariable in these European regions, that does not mean each component does not hold a distinct weight and evolutionary dynamics in different regions. As confirmatory factors draw a clearer distinction between different dimensions of social capital, these factor scores are also a good basis for us to have an idea of social capital levels and trends at the regional level. On the basis of the obtained social capital factors we used an ANOVA statistics to find out the mean differences in social capital components between European regions from 2002 to 2010.

If we take into account each component in 2010, the inter-regional differences are quite obvious: mean scores of social networks are higher in Northern and Western Europe and quite low in Southern and Eastern Europe. There is a statistically significant strengthening of social networks in the scope of civil society only in Northern Europe between 2002 and 2010. In parallel fashion, we observe a declining trend in Western Europe and a certain stability in remaining regions, even if not statistically significant.

The same pattern repeats itself regarding synchronic generalized and institutional social trust. However, diachronically we see a decline of this component in Northern Europe even if it is not statistically significant, unlike in Southern Europe ( $(=-.082)$ and Eastern Europe $(B=-.067)$.

Table 1. Mean Comparison of Second-Order Components of Social Capital (2010)

\begin{tabular}{|c|c|c|c|c|c|c|}
\hline & & $\mathrm{N}$ & Mean & Std. Dev. & $\begin{array}{c}\text { ANOVA } \\
F(6.34078)\end{array}$ & $P$ \\
\hline \multirow{6}{*}{ 1. Social Networks } & Nordic & 6502 & 0.22 & 1.02 & 295.862 & $<0.001$ \\
\hline & Western and Central Europe & 9798 & 0.18 & 0.98 & & \\
\hline & Britain - Ireland & 2422 & -0.18 & 0.91 & & \\
\hline & Southern Europe & 4035 & 0.02 & 0.96 & & \\
\hline & Eastern Europe & 7101 & -0.22 & 0.95 & & \\
\hline & Baltic & 1793 & -0.58 & 0.97 & & \\
\hline \multirow[t]{6}{*}{ 2. Social and Institutional Trust } & Nordic & 6502 & 0.90 & 0.75 & 2.474 .517 & $<0.001$ \\
\hline & Western and Central Europe & 9798 & 0.22 & 0.82 & & \\
\hline & Britain - Ireland & 2422 & 0.13 & 0.82 & & \\
\hline & Southern Europe & 4035 & -0.42 & 0.82 & & \\
\hline & Eastern Europe & 7101 & -0.38 & 0.89 & & \\
\hline & Baltic & 1793 & 0.08 & 0.90 & & \\
\hline \multirow[t]{6}{*}{ 3. Political and Civic Awareness } & Nordic & 6502 & 0.09 & 1.02 & 72.301 & $<0.001$ \\
\hline & Western and Central Europe & 9798 & 0.07 & 0.98 & & \\
\hline & Britain - Ireland & 2422 & -0.05 & 1.02 & & \\
\hline & Southern Europe & 4035 & -0.12 & 0.96 & & \\
\hline & Eastern Europe & 7101 & -0.14 & 0.95 & & \\
\hline & Baltic & 1793 & -0.26 & 0.96 & & \\
\hline \multirow[t]{6}{*}{ 4. Social Cohesion } & Nordic & 6502 & 0.15 & 0.91 & 129.109 & $<0.001$ \\
\hline & Western and Central Europe & 9798 & 0.10 & 0.95 & & \\
\hline & Britain - Ireland & 2422 & -0.13 & 1.02 & & \\
\hline & Southern Europe & 4035 & -0.22 & 0.87 & & \\
\hline & Eastern Europe & 7101 & -0.12 & 1.00 & & \\
\hline & Baltic & 1793 & -0.22 & 0.97 & & \\
\hline
\end{tabular}

Source: European Social Survey (2010)

Regarding civic norms and political conscience, we found that average values are higher and positive in Northern and Western Europe, contrasting with the negative average values in Southern Europe ( $B=-.012)$. Furthermore, there is a statistically significant decrease of this component $(B=-.084)$ between 2002 and 2010.

Lastly, the feeling of social cohesion and community is an especially strong dimension in Northern Europe and, although less, in Western Europe in 2010. We see a slight decline of the component in 2002-2010, contrasting with its strengthening in Northern Europe, even if it is not statistically significant. However, what we observe in Southern Europe is quite different, since average social cohesion and community feeling values are negative and statistically significant ( $B$ $=-.022)$. The same occurs, to a smaller degree, in the region of England and Ireland $(B=-.013)$. Diachronically, there is a declining trend in Southern and Eastern Europe, even if not statistically significant. 
Table 2. Social Network trends in European regions, 2002-2010 (standardized mean values)

\begin{tabular}{lcccccccc}
\hline & 2002 & 2004 & 2006 & 2008 & 2010 & $\begin{array}{c}\text { Net Change } \\
(2002-2010)\end{array}$ & Year & Sig. \\
\hline Western Europe & 0.063 & 0.041 & 0.068 & 0.048 & 0.047 & -0.016 & 0.004 & 0.298 \\
Northern Europe & 0.430 & 0.292 & 0.307 & 0.189 & 0.264 & $0.166^{* \prime}$ & -0.017 & 0.088 \\
Eastern Europe & -0.227 & -0.211 & -0.200 & -0.217 & -0.221 & 0.006 & 0.012 & 0.133 \\
Southern Europe & -0.185 & -0.172 & 0.008 & -0.180 & -0.012 & 0.173 & 0.031 & 0.309 \\
\hline
\end{tabular}

Table 3. Social and Institutional trust trends in European regions, 2002-2010(standardized mean values)

\begin{tabular}{lcccccccc}
\hline & 2002 & 2004 & 2006 & 2008 & 2010 & $\begin{array}{c}\text { Net Change } \\
(2002-2010)\end{array}$ & Year & Sig. \\
\hline Western Europe & 0.144 & 0.146 & 0.141 & 0.158 & 0.144 & 0.000 & 0.006 & - \\
Northern Europe & 0.566 & 0.428 & 0.492 & 0.328 & 0.501 & -0.065 & -0.027 & 0.138 \\
Eastern Europe & -0.305 & -0.392 & -0.431 & -0.444 & -0.372 & $-0.067^{* *}$ & -0.012 & 0.015 \\
Southern Europe & -0.178 & -0.222 & -0.164 & -0.293 & -0.259 & $-0.082^{* *}$ & 0.003 & 0.012 \\
\hline
\end{tabular}

Source: European Social Survey (2002-2010)

Table 4. Political and civic awareness trends in European regions, 2002-2010 (standardized mean values)

\begin{tabular}{lcccccccc}
\hline & 2002 & 2004 & 2006 & 2008 & 2010 & $\begin{array}{c}\text { Net Change } \\
(2002-2010)\end{array}$ & Year & Sig. \\
\hline Western Europe & 0.023 & 0.000 & -0.022 & 0.023 & 0.017 & -0.005 & 0.001 & 0.683 \\
Northern Europe & 0.021 & 0.003 & 0.032 & 0.013 & 0.077 & 0.056 & 0.012 & 0.499 \\
Eastern Europe & -0.060 & -0.113 & -0.081 & -0.081 & -0.081 & -0.021 & -0.009 & 0.354 \\
Southern Europe & -0.050 & -0.037 & -0.081 & -0.040 & -0.134 & $-0.084^{*}$ & -0.012 & 0.033 \\
\hline
\end{tabular}

Table 5. Social cohesion and sense of community trends in European regions, 2002-2010 (standardized mean values)

\begin{tabular}{lcccccccc}
\hline & 2002 & 2004 & 2006 & 2008 & 2010 & $\begin{array}{c}\text { Net Change } \\
(2002-2010)\end{array}$ & Year & Sig. \\
\hline Western Europe & 0.118 & 0.051 & 0.026 & 0.099 & 0.047 & $-0.005^{\circ}$ & 0.005 & 0.094 \\
Northern Europe & 0.288 & 0.163 & 0.243 & 0.175 & 0.252 & 0.056 & 0.009 & 0.534 \\
Eastern Europe & -0.123 & -0.162 & -0.163 & -0.139 & -0.181 & -0.021 & 0.006 & 0.287 \\
Southern Europe & -0.228 & -0.323 & 0.010 & -0.261 & -0.019 & -0.084 & 0.018 & 0.501 \\
\hline
\end{tabular}

Source: European Social Survey (2002-2010)

\section{Comparison of the determinants of social capital}

\subsection{Individual-level determinants of social capital}

Throughout the analysis, the four components or dimensions of social capital - as derived from confirmatory factor analysis - are used as dependent variables in our OLS regression models. The selection of independent variables is based on theoretical considerations and on the availability of respective data in the European Social Survey. The exact descriptions of the selected 21 individual-level indicators used as independent variables in OLS regressions are presented in the Appendix D. These individual-level determinants of social capital are divided into three subsets. Firstly, socio-economic factors like gender, age, education, income, relationship status, size of household, employment status and diversity of country, ethnic minorities or discriminated groups are also included in this subset.

Secondly, the following psychological and cultural factors are considered: religion, religiosity, and evaluative thought streams, such as universalism, individualism, hedonism and post-materialism, but also consumption of information through the old and new media. The final subset includes the evaluation that citizens make the performance of political institutions and the country's state of economy.

Full regression results of individual-level determinants of social capital go in two lines. Firstly, the effect of alternative influencing factors is analysed by separate social capital components, which are organised by broader dimensions (second-order factor). Secondly, the results are (re) presented from the viewpoint of influencing factors, focusing on two questions: which of them have the largest (or most widespread) effect on social capital in each European 
region, and whether the results are in accordance with previous theoretical expectations and empirical work on this subject.

\subsection{What does the literature teach and the data show us?}

\subsubsection{Social networks' individual determinants}

As regards employment status, the previous empirical findings are somewhat ambiguous. It has been proved that a person facing unemployment has a strong disincentive to participate in social groups, partly on account of the distrust he/she tends to develop towards society. It may admit that being unemployed translates into more limited access to both informal and formal networks, being employed has the opposite influence. The fact of being outside the labour market for a long time already, its explanatory capability in support of citizens to formal and informal social networks takes an explanatory power with a weak statistical significance in the case of Northern Europe ( $B=.102)$ (see Appendix B).

In Northern Europe and Western Europe, education appears as the strongest predictor and statistically positive with regard to the formation of social networks ( $B=.041$ and $B=0.46$ ), being still a strong and also positive predictor in the region which includes Britain and Ireland $(B=.034)$ and also in the case of Southern Europe $(B=.042)$. As for income, the level of statistical significance is strong and positive only in Eastern Europe $(B=.124)$, the average being in the Baltic countries $(B=.101)$ and in Britain and Ireland $(B=.034)$ (see Appendix $B$ ).

On the other hand, Putnam (1993) suggests that high levels of civic engagement are found among older people. The age factor proves to be one of which features a stronger significance level and always in the negative sense, confirming that young people are the least adhere and participate in social networks, or by civic demobilization or opt for other forms of public intervention. Is so in Northern Europe $(p=.000)$, Western Europe $(p=.008)$, in Britain and Ireland $(p=.008)$, but also in the Baltic countries $(p=000)$.

Concerning gender, previous research has shown that women tend to have significantly lower levels of overall civic participation in social networks (Christoforou, 2005). The movement of women out of the home and into the paid labour force is probably the most portentous social change of the last half-century. But, with the exception of Northern Europe $(B=-.176)$, the emergence of two-career families might still be the most important single factor to explain that women are less present on social networks than men, as is the case in Western and Central Europe $(B=.147)$ and Eastern Europe ( $(=.121)$.

In Western Europe the fact that being a citizen of the country positively and strongly influences the membership of social networks $(B=.171)$, and being a member of a group discriminated against within the country strengthens much training and participation in social networks, notably in Northern Europe $(B=.328)$ and Western Europe $(B=.168)$ and, albeit more moderately, in Eastern Europe ( $\beta=.171)$ and Southern Europe ( $(=.334)$ (see Appendix $B$ ).

Social capital has some of its roots in history and related ideology. In general, an ideology - for example, religion and religiosity - can create social capital by forcing its followers to act in the interests of something or someone other than themselves (Knack and Keefer, 1997). Religiosity or religion attendance in general has been found to have a positive impact on both formal and informal social networks. In our analysis, if the role of religion is statistically significant in the majority European regions (perhaps because it is the Catholic religion), the fact is that religiosity or religion attendance is a strong and positive predictor of social networks, a conclusion which is extensible to Northern Europe ( $B$ $=.101)$, Western and Central Europe $(B=.101)$, Eastern Europe $(B=.046)$ and, to a lesser extent, Ireland and Britain ( $(B$ $=.056)$.

Given the influence of cultural values under the first component of capital we must underline the negative role in the formation of social networks, both of the individualism and hedonism, marked by the culture of the pursuit of individual success and well-being, as well as the culture of excess, of pleasure, of consumption in almost all European regions (see Appendix B).

With regard to institutional variables, its explanatory capability in the regression model shows above all the importance of reconciling two types of approaches: on the one hand, the approach centred on society, on the other hand, the approach centred on institutions. And why? Because above all with regard to social networking, this is far from being, in many regions, indifferent to the state of the country's economy and, consequently, the performance of the government in functions. In effect, with the exception of the Baltic States, the negative review that citizens make of their country's economic situation and the government's performance in this area of governance have a statistically strong and negative influence on the creation of social networks. It is curious to note that with regard to the policies of the state in the social redistribution expenditure, the more favourable it is evaluating citizens against a restrict social-democratic model welfare 
state, the less the creation and support of citizens for social networks. It shows that countries/regions that have higher public social spending also have a lower tendency for associations or social activism (Ervasti, 2012).

\subsubsection{Social and institutional trust individual determinants}

Social and institutional trust as one of the basic components of social capital has three main positive determinants, which include a reasonable number of regions: people who are more trusting are more educated, make greater personal use of the Internet and are more satisfied with the welfare state's performance. In addition, lower trust is associated with several determinants in some European regions: lower individualism (Eastern Europe and Baltic), hedonism (Western Europe, Eastern Europe, Baltic states, Southern Europe and Northern Europe) and lower support for post-materialist values (Northern, Western and Eastern Europe).

Lower trust also has associates with citizen's negative evaluation of the political and economical performance of government, a reality that extends to almost all - if not all - European regions considered here. Clear enough is also the negative between social and confidence in political institutions and the exposure to the old media (TV). As in the case of the Nordic countries $(B=-.037)$, in the Baltic countries $(B=-.041)$, and so much more moderate in Western European countries $(\beta=-.010)$.

If we compare them with the positive influence the new media (Internet) has on citizen confidence especially in Northern Europe $(B=.023)$, in Western and Central Europe $\beta(=.027)$ and, in a smaller scale, in England and Ireland ( $\beta$ $=.017)$. These data would lead us to discuss the role of old and new media, citizen trust in institutions and political actors and towards the debate around the two main theses regarding political communication in existing literature. The first theory arose from the 'video-malaise' theory and focuses on the type of media and the tone of media coverage (Robison, 1976) and the theory of the 'virtuous circle', the type of media and the message (Newton, 1997).

Contemplating the institutional variables, it is evidently easy to see the negative consequences, statistically strong and negative, that the poor performance of government in economic and political trust has on the social and institutional citizens, which seems to give reason to the analysis of Pippa Norris (2011) on the determinants of the democratic deficit in the contemporaneous democracies reside more on the supply side than on the demand side.

\subsubsection{Civic norms and political awareness individual determinants}

In almost all European regions, older persons, men, educated and employed people are more civic and attentive to politics. Moreover, people who support the universal and post-materialist values (Northern and Western European countries among other regions are more civic than those supporting individualistic and hedonistic values) (Inglehart 1977, 1990; Inglehart, 1997; Inglehart and Abramson, 1995; Inglehart and Norris, 2004; Inglehart and Wezel, 2005).

If we take into account the mass media effect, both old and new have a positive statistical significance effect on this component, as occurs mainly in Western and Central Europe, England and Ireland, but also in Northern Europe. This means there is a complementarity effect in most regions, and not a substitution one (see Appendix B). In other words, this suggests that the Internet helps to increase existing patterns of civic and political awareness (Wellman et al, 2002).

As institutional variables in the civic and political consciousness concerns we can observe that, in the majority of European regions, the negative evaluation of the performance of government both politically and economically has a negative and statistically strong effect in this dimension of social capital. It should also be stressed that in some European regions citizens' civic conscience tends to be higher, namely where they positively assess public policies related to the Welfare State (national health care, education, social security). This occurs, for example, in Western and Central Europe $(B=.034)$, Southern Europe $(B=.217)$ and Eastern Europe $(B=.147)$.

\subsubsection{Sense of social cohesion and community individual determinants}

Lastly, let us look at the most important determinants of social cohesion and sense of community in European regions. As we can see Appendix B, the national citizens with a higher level of education, post-materialist and universalistic values tend to have a higher sense of social cohesion and community. This allows individuals to live in a society with a certain consensus and social order. Besides, this trend is transverse and common to all European regions we have analyzed.

It should be noted that social cohesion refers to two broader, intertwined features of society: 1) the absence of latent social conflict - whether in the form of inequalities in income or wealth, racial and ethnic tensions, disparities in 
political participation, or other forms of polarization; 2) the presence of strong social bonds - measured by levels of trust and norms of output started at (i.e. social capital); the abundance of associations that bridge social divisions ('civil society'; and the presence of institutions of conflict management (e.g. the responsive democracy, an independent judiciary, etc.). Social capital can therefore be seen as forming a subset of social cohesion - a cohesive society is also one that is richly endowed with stocks of social capital (Hooghe, 2007).

Summing up, generalizing the above results, it can be concluded that different components of social capital have different sources or the same sources but that simply vary statistically direction and magnitude according to the different European regions, so proposition $\mathrm{P} 2 \mathrm{a}$ is supported. More specifically, social networks and civic and political awareness (structural aspects of social capital), on the hand, generalized and institutional trust and sense of social cohesion, on the other, are mostly influenced by socio-economic and demographic factors or else by cultural and psychological (cognitive aspects of social capital) depending on the regions at stake. However, there is a caveat to that as follows: institutional variables affect statistically with the same strength and direction almost all components of the social capital in almost all European regions considered in our analysis.

\section{Individual- and macro-level determinants of social capital}

The previous analysis of social capital' determinants at the level of individuals is complemented by national-level indicators, in order to find out whether these contextual factors affect the individual amount of social capital. Selection of national-level indicators is based mostly on theoretical considerations, but also on previous empirical studies in order to ensure the comparability of the results, and on the availability of reliable data for the countries of interest. In the following analysis, national-level determinants of social capital are divided into two groups. The first set of independent variables includes the democratic consolidation (years after the establishment of the democratic regime in the country) and the analysis of the Corruption Perceptions Index (proxy for institutional government quality) (see Appendix C).

Second, indicators related to the overall development level of a country, which are measured directly at the national level, are included in the analysis. These indicators comprise GDP per capita (measuring the overall wealth), the Gini index (measuring the income inequality), human capital (including education and health sub-indices from HDI), and a composite factor named 'communication', which measures the spread of modern communication tools (telephones, mobiles and the Internet) and is often referred to as the globalization indicator in the literature (see Appendix C).

When comparing the goodness of fit of the individual-level social capital models, which include different sets of determinants (see the values of adjusted $\mathrm{R}_{2}$ ), the following conclusions can be drawn about the interplay of individual and national determinants. Firstly, models, which consider both individual- and national-level determinants, are better than those including only micro-level determinants. Secondly, when comparing the models with only micro-level or only national-level determinants, the values of adjusted $\mathrm{R}_{2}$ are mostly higher in the case of the former, indicating the higher importance of individual-level factors as compared to contextual factors.

Among measured national-level variables, the greater the income inequality, the perception of corruption and the difficulty of access to modern communications, the lower the tendency for the creation of social networks in some of the regions of Europe (see Appendix B). Regarding the public expenditure on health and education, corruption appears to be most influential in the formation of social networks. At the national level, it seems that state intervention enables those voluntary organizations to flourish that can be characterized more properly as part of civil society than as alternatives to government social welfare providers.

As regards the second component of social capital, social and institutional trust, the national variables' most influential statistically and positively are the State spending on health and education, the human development index and GDP per capita. Even in respect of cognitive capital, data show that in some regions there is a statistical inversely proportional relationship between the control of corruption, the inequality of income (e.g. Northern Europe) and the longevity of democratic regimes (Western Europe) and trust in other people and in political institutions (see Appendix C).

Both in Western Europe and in Southern Europe, the Human Development Index is a strong national and statistically significant determinant, because the greater the HDI the higher the level of civic and political consciousness of citizens. Just one more determinant deserves equal emphasis here and it is related to the public policies of redistribution in social areas that appear to strengthen also the civility and attention that the citizens give to public affairs.

The sense of social cohesion is statistically strong and positively related to the longevity of the democracy, the Human Development Index, per capita product and to a more or less universalist model welfare state (see Appendix C). In turn, the sense of social cohesion is negatively related to the perception that there is widespread corruption in the country and that the development of modern communications and access to them in the country is far from desirable. 
Altogether, these results support both the proposition P2b in that different components of social capital at individual level are influenced differently by proposed macro-level determinants.

\section{Conclusions}

According to our theoretical framework, we should bear in mind that different components of social capital may have different determinants and effects. Therefore, a dimensional approach that avoids constructing overly aggregated or additive social capital indexes is preferred. We set up some propositions based on these considerations. We will now review them and their empirical validity based on the results of the empirical analysis we got throughout the article.

P1a: The components of social capital are robust and similar in European regions.

The analysis fully supports this proposition. The exploratory factor analysis and the confirmatory factor analysis resulted in similar components in the subsamples (although with a slightly different relative importance in terms of variance explained by separate factors).

P1b: Although social capital structure is the same in European regions, its levels may differ both diachronically and synchronically.

This proposition was mostly supported by the comparison of mean component scores belonging to second-order components of social capital by European regions. The gap in social capital levels in favor of Northern, Western and Central Europe was highest in almost all social capital components. This is apparently attributable to the lower development and the lower level of democracy consolidation of other regions, such as Eastern Europe and, to a lesser degree, Southern Europe. Diachronically, the average differences regarding the evolution of each of social capital's component keeps this gap more or less unchanged.

P2a: The individual-level determinants are expected to have different effects (in the direction and magnitude) on social capital components in European regions.

This proposition was confirmed. At the individual level, it is a general idea that networks and civic commitment are mostly influenced by socio-economic and demographic factors (the structural aspect of social capital), while cultural and psychological factors are dominant regarding trust and sense of community (cognitive aspect of social capital). Concerning the effect of national-level determinants on individual-level social capital, pooled regression results also support the claim that dissimilar components are differently influenced by the proposed determinants.

P2b: The relative importance of micro and macro-level factors might be different in European regions, in the case of different social capital components.

The analysis supports this proposition. Regression results showed that the proposed factors - GDP per capita, income inequality, human capital and corruption control - often have dissimilar effects on individual social capital in European regions. It is still interesting to note that the goodness of fit (on the basis of adjusted $\mathrm{R}^{2}$ ) of the regression models, with different sets of social capital determinants, was compared.

Apparently the models that consider both individual and national-level determinants are better than those who only include micro or national-level determinants. This result occurs in both European region subsamples and in all social capital components. Furthermore, when comparing the models with only micro-level or national-level determinants, the adjusted $R^{2}$ values are mostly higher in the former, indicating the higher importance of individual-level factors when compared to contextual factors.

\section{References}

Arneil B. (2006) Diverse Communities: The Problem with Social Capital. Cambridge: Cambridge University Press.

Boix C. and Posner DN (1996) Making social capital work: A review of Robert Putman's 'Making Democracy Work: Civic Traditions in Modern Italy'. Comparative Politics Harvard Working Paper 96-04. Weatherhead Center for International Affairs, Harvard University.

Bourdieu P. (1984) Distinction: A Social Critique of the Judgement of Taste. London: Routledge.

Bourdieu P (1985) The forms of capital. In Richardson JG (ed.), Handbook of Theory and Research for the Sociology of Education. New York: Greenwood, 241-58.

Coleman JS (1986) Individual Interest and Collective Action. Selected Essays. Cambridge: Cambridge University Press.

Coleman JS (1990) Foundations of Social Theory. Cambridge, Mass.: Harvard University Press.

Dasgupta P and Serageldin I (eds) (1999) Social Capital. A Multifaceted Perspective. Washington, D.C.: The World Bank.

Durlauf SN (2002) On the empirics of social capital. The Economic Journal 112: 459-479.

Ervasti H, Andersen JG, Fridberg T, Ringdal K (eds) (2012) The Future of the Welfare State. Social Policy Attitudes and Social Capital in Europe. Northampton Massachusetts: Edward Elgar Publishing.

Grootaert C and Van Bastelaer T (2000) Understanding and Measuring Social Capital. A Multidisciplinary Toll for Practitioners. Washington, D.C.: The World Bank.

Hjollund L and Svendsend GT (2000) A Standard Method of Measurement. Aarhus School of Business - Department of Economics Research Working 
Paper 00-9.

Hooghe M (2007) Ethnocentrism. In: International Encyclopedia of the Social Sciences. Philadelphia: MacMillan.

Inglehart R (1977) The Silent Revolution. Princeton: Princeton University Press.

Inglehart R (1990) Culture Shift in Advanced Industrial Society. Princeton: Princeton University Press.

Inglehart R (1997) Modernization and Postmodernization, Princeton University Press.

Inglehart R and Abramson PR (1995) Value Change in Global Perspective. University of Michigan Press.

Inglehart R and Norris P (2004) Sacred and Secular: Religion and Politics Worldwide. Cambridge University Press.

Inglehart R and Welzel C (2005) Modernization, Cultural Change and Democracy: The Human Development Sequence. Cambridge University Press.

Knack S and Keefer P (1997) Does social capital have an economic payoff? Across-country investigation. Quarterly Journal of Economics $112(4)$ : 1251 1288.

Lin N (2001) Building a network theory of social capital. In: Lin N, Cook KS and Burt RS (eds) Social Capital: Theory and Research. New York: Aldine de Gruyter, 3-29.

Lin N (2002) Social Capital. A Theory of Social Structure and Action. Cambridge: Cambridge University Press

Newton K (1997a) Social capital and democracy. American Behavioural Scientist 40(5): 575-586.

Newton K (1997b) Politics and the news media: Mobilisation or video-malaise? In: Jowell R, Curtice J, Park A et al. (eds) British Social Attitudes. The 14th Report. Aldershot: Ashgate.

Paldam M and Svendsen GT (2000) Missing social capital and the transition in Eastern Europe. Aarhus School of Business - Department of Economics Research Working Paper 00-5.

Parts E (2009) Social Capital, its determinants and relations with economic growth: comparison of the Western European and Central and Eastern countries. University of Tartu.

Putnam, RD (1993) Making Democracy Work. Civic Traditions in Modern Italy. Princeton NJ: Princeton University Press.

Putnam RD (1995) Bowling alone: America's declining social capital, Journal of Democracy 6(1): 65-78.

Putnam RD (2000) Bowling Alone. The Collapse and Revival of American Community, New York: Simon and Schuster.

Robison M (1976) Public affairs television and the growth of political malaise: the case of 'selling of the president'. American Political Science Review 70(3): 409-432.

Rothstein B (2001) Social capital in the social democratic welfare state. Politics \& Society 29(2): 207-41

Svendsen GT and Svendsen LH (2009) The Troika of Sociology, Political Science, and Economics. Massachusetts: Edward Elgar Publishing Limited.

Uphoff N (2000) Understanding social capital: learning from the analysis and experience of participation. In: Dasgupta P and Serageldin I (eds) Social Capital: A Multifaceted Perspective. Washington, D.C.: World Bank.

Uslaner EM (2003) Trust and civic engagement in East and West. In: Badescu G and Uslaner EM (eds) Social Capital and the Transition to Democracy. London: Routledge, 81-94.

Wellman B, Quan-Haase A, Witte J and Hampton K (2002) Does the internet increase, decrease, or supplement social capital? Social capital networks, participation, and community commitment. The American Behavioral Scientist Research Working Paper 45: 436-55.

\section{Appendix A}

Table 1. Confirmatory Factor Analysis for First Order Model

\begin{tabular}{|c|c|c|c|c|c|c|}
\hline \multicolumn{7}{|c|}{ ESTIMATES } \\
\hline DIMENSION & VARIABLE & UNSTANDARDIZED & STANDARDIZED & S.E. & TEST-T & $\mathrm{P}$ \\
\hline \multirow[t]{2}{*}{ 1.1. Informal network } & a1.1.1 & .932 & .455 & .046 & $20.177^{*}$ & $<0.001$ \\
\hline & a1.1.2 & 1.000 & .822 & & & \\
\hline \multirow[t]{2}{*}{ 1.2. Formal network } & a1.2.1 & .345 & .229 & .031 & $11.178^{*}$ & $<0.001$ \\
\hline & a1.2.1 & 1.000 & .705 & & & \\
\hline \multirow[t]{3}{*}{ 2.1. Generalized trust } & a2.1.1 & 1.217 & .766 & .011 & $111.434^{*}$ & $<0.001$ \\
\hline & a2.1.2 & 1.092 & .740 & .010 & 110.213 & $<0.001$ \\
\hline & a2.1.3 & 1.000 & .668 & .010 & & \\
\hline \multirow[t]{4}{*}{ 2.2. Institutional trust } & a2.2.1 & 1.162 & .842 & .007 & 167.996 & $<0.001$ \\
\hline & a2.2.2 & 1.184 & .819 & .007 & 163.558 & $<0.001$ \\
\hline & a2.2.3 & .976 & .695 & .007 & $136.707^{*}$ & $<0.001$ \\
\hline & a2.2.4 & 1.000 & .786 & .007 & & \\
\hline \multirow[t]{5}{*}{ 3.1. Civic norms } & a3.1.1 & 1.172 & .577 & .016 & 74.155 & $<0.001$ \\
\hline & a3.1.2 & .853 & .335 & .017 & 50.149 & $<0.001$ \\
\hline & a3.1.3 & 1.251 & .669 & .016 & 77.416 & $<0.001$ \\
\hline & a3.1.4 & 1.019 & .448 & .016 & $63.126^{*}$ & $<0.001$ \\
\hline & a3.1.5 & 1.000 & .601 & & & \\
\hline \multirow[t]{4}{*}{ 3.2. Political attachment } & a3.2.1 & .744 & .542 & .016 & 46.320 & $<0.001$ \\
\hline & a3.2.4 & 1.133 & .568 & .024 & $46.504^{*}$ & $<0.001$ \\
\hline & a3.2.5 & 1.000 & .439 & & & \\
\hline & a3.2.6 & .770 & .601 & .017 & 45.747 & $<0.001$ \\
\hline \multirow[t]{3}{*}{ 4. Social cohesion } & a4.1.1 & .967 & .774 & .006 & 150.698 & $<0.001$ \\
\hline & a4.1.2 & 1.071 & .824 & .007 & $156.119^{*}$ & $<0.001$ \\
\hline & a4.1.3 & 1.000 & .840 & & & \\
\hline
\end{tabular}

Table 2. Confirmatory Factor Analysis Results for Second Order Model

\begin{tabular}{|c|c|c|c|c|c|c|}
\hline \multicolumn{7}{|c|}{ ESTIMATES } \\
\hline DIMENSION & VARIABLE & UNSTANDARDIZED & STANDARDIZED & S.E. & TEST-T & $P$ \\
\hline \multirow[t]{2}{*}{ 1. Social network } & a1.1 & 2.240 & .280 & .071 & $31.442^{\star}$ & $<0.001$ \\
\hline & a1.2 & 1.000 & .477 & & & \\
\hline \multirow[t]{2}{*}{ 2. Social and institucional trust } & a2.1 & .568 & .638 & .008 & $72.479^{\star}$ & $<0.001$ \\
\hline & a2.2 & 1.000 & .756 & & & \\
\hline \multirow[t]{2}{*}{ 3. Civic and political awareness } & a3.1 & .423 & .178 & .026 & $16.040^{*}$ & $<0.001$ \\
\hline & a3.2 & 1.000 & .508 & & & \\
\hline \multirow[t]{3}{*}{ 4. Social cohesion } & a4.1.1 & .970 & .775 & .006 & 153.282 & $<0.001$ \\
\hline & a4.1.2 & 1.074 & .824 & .007 & $160.169^{\star}$ & $<0.001$ \\
\hline & a4.1.3 & 1.000 & .839 & & & \\
\hline
\end{tabular}




\section{Appendix B}

Table 1. Social networks individual-level determinants

\begin{tabular}{|c|c|c|c|c|c|c|c|c|c|c|c|c|c|c|c|c|c|c|c|c|c|c|c|c|}
\hline & \multicolumn{4}{|c|}{ Northem Europe } & \multicolumn{4}{|c|}{$\begin{array}{l}\text { Westerm and Central } \\
\text { Europe }\end{array}$} & \multicolumn{4}{|c|}{ Britain-rreland } & \multicolumn{4}{|c|}{ Southem Europe } & \multicolumn{4}{|c|}{ Eastern Europe } & \multicolumn{4}{|c|}{ Ballic States } \\
\hline & B & S.E. & t & $p$ & B & S.E. & t & p & $B$ & S.E. & $\mathrm{t}$ & $p$ & B & S.E. & $\mathrm{t}$ & p & $B$ & S.E. & $\mathrm{t}$ & $\mathrm{p}$ & $B$ & S.E. & $t$ & \\
\hline Ender(male) & -176 & .032 & .5 .545 & .000 & \begin{tabular}{|l|l|}
.147 \\
\end{tabular} & .022 & 6.604 & .000 & \begin{tabular}{ll|l|}
.031 & \\
\end{tabular} & .044. & .712 & .477 & .048 & .054 & 893 & 372 & .121 & .0284 & 4.335 & .000 & .042 & .054. & .771 & \\
\hline (in year & .006 & .001 & -4.009 & .000 & .002 & .001 & -2.637 & .008 . & .005 & $.002 \cdot 2.25 y$ & -2.639 & .008 & .002 & .002 & .912 & 362 & .000 & .001 & .282 & .778 & .009 & $.002=3$ & -3.625 & \\
\hline Ication & .041 & .009 & 4.388 & .000 & .046 & .007 & 6.640 & .000 & .034 & . 0132 & 2.628 & .009 & .042 & . 0162 & 2.724 & .007 & .019 & . 0101 & 1.849 & .065 & .022 & . 0171 & 1.314 & \\
\hline usehold'st & .015 & .026 & .551 & .582 & .020 & . 017 & -1.199 & .231 & .029 & .031 & .935 & .350 & .027 & .037 & .717 & 474 & .124 & . 0196 & 6.598 & .000 & .101 & . 0392 & 2.586 & \\
\hline in sith & .102 & .044 & 2.300 & .021 & .010 & .027 & .347 & .729 & .030 & .058 & .522 & .602 & .073 & .0601 & 1.225 & .221 & .025 & .037 & .688 & 4922 & .003 & & .043 & \\
\hline tial sta & .009 & .036 & .251 & .802 & -117 & .026 . & .4.569 & .000 & .041 & .051 . & .813 & .416 & .029 & .058 .058 . & .498 & 619 & .006 & .030 . & .212 & .832 & . 090 & .057 & 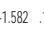 & \\
\hline e of hh & -044 & . 015 & -2.857 & .004 & .009 & .011 & .830 & . 407 . & .034 & . 021.1 & -1.586 & .113 & .020 & .022 & .879 & 380 & .010 & . 012 & .820 & .412 & .057 & . 023 & 2.534. & \\
\hline Bomin cou & .085 & .063 & 1.349 & .178 & .171 & .039 & 4.437 & .000 & .140 & .084 1 & 1.666 & .096 & .212 & 1071 & 1.982 & .048 & .141 & . 0731 & 1.918 & .055 & .132 & .090 1 & 1.469 : & \\
\hline mber of of liscinininated group & .328 & .068 & 4.848 & .000 & .168 & .0473 & 3.562 & .000 & .226 & .0683 & 3.329 & .001 & .334 & . 1282 & 2.604 & .009 & .171 & .0612 & 2.801 & .005 & .202 & .1191 & 1.703 & \\
\hline Belong to & .131 & . 099 & 1.327 & .185 & -069 & .060 & -1.157 & .247 & .025 & . 108 & .231 & .818 & .180 & . 1641 & 1.100 & .272 & .152 & . & 1.731 & .083 & . 093. & .097 & .967 & \\
\hline Belo & -117 & .264 & . .443 & .658 & .095 & .206 & .460 & .646 & .357 & 310. & -1.153 & .249 & . .779 & .5661 & 1.376 & 169 & .617 & .3421 & 1.802 & .072 & .999. & .3812 & 2.619 & \\
\hline Religion attendann & .101 & . 016 & 6.121 & .000 & .070 & . 010 & 6.962 & .000 & .056 & .0202 & 2.773 & .006 & . 019 & . 022 & 864 & .387 & .046 & .013 3 & 3.427 & .001 & .012 & . 028 & . 416 & \\
\hline Universali: & .012 & .015 & .846 & .398 & .011 & . 011 & .973 & .331 & .024 & .021 .1 & -1.141 & .254 & . 016 & .034 & .472 & .637 & .031 & .0142 & 2.209 & .027 & .058. & .025 & -2.343 & \\
\hline dvividuala & .032 & . 017 & -1.882 & .060 & -020 & . 012. & -1.730 & . 084 & .002 & .024 & .068 & .945 & . & . 028 . & 4.226 & .000 & .054 & . 015 & -3.485 & .000 & .068. & . 029. & -2.386 & \\
\hline Hedor & .099 & .015 & 6.570 & .000 & .082 & . 011 & 7.361 & .000 & .120 & .021 5 & 5.795 & .000 & .109 & .026 & 4.195 & .000 & .086 & 6. & -6.617 & .000 & .107. & .028 3 & 3.868 & \\
\hline Post-Materialism & .006 & .025 & .243 & .808 & .024 & . 015 & 1.619 & . 106 . & .023 & . 033 & . .702 & .483 & .092 & .0392 & 2.351 & .019 & .032 & .017 & -1.874 & 061 & .029. & .036 & .818 & \\
\hline TVRRadio & .039 & . 013 & -2.897 & .004 & .003 & .009 & .316 & .752 & .008 & .018 & .431 & .666 & .031 & . $023 \mathrm{~s}$ & 1.328 & .184 & .003 & .011 & .314 & .754 & .043. & .021 & 2.048 & \\
\hline Person & .055 & .008 & 6.532 & .000 & .047 & .005 & 9.705 & .000 & .026 & . 0102 & 2.639 & .008 & . 039 & .0123 & 3.154 & .002 & .032 & .0065 & 5.296 & .000 & .021 & . & 1.572 & 11 \\
\hline Political g & .009 & .008 & 1.139 & .255 & .021 & .006 & -3.805 & .000 & .005 & .011 & .506 & .613 & . 024 & . 0151 & 1.579 & .115 & $\mid-207$ & .007 & -1.004 . & .015 & .049 . & . 016 & .3 .101 & \\
\hline Econd & .032 & .008 & -3.734 & .000 & -027 & .006 & -4.521 & .000 & .054 & . 013. & -4.244 & .000 & .029 & . 017 & 1.097 & .003 & .050 & $.008 \cdot 6$ & 6.250 & .000 & .031 . & .016 & .1 .987 & \\
\hline Weffare State & .048 & .010 & 4.807 & .000 & .027 & . & -4.551 & .000 & .029 & . & -2.277 & .023 & . & . 016 & 2.155 & .031 & .039 & .007 & 5.590. & .000 & .043. & & & \\
\hline & 0.130 & & & & 0.100 & & & & 0.126 & & & & 0.132 & & & & 0.091 & & & & \begin{tabular}{l|l|l|l|l} 
&
\end{tabular} & & & \\
\hline Adjusted $\mathrm{R}^{2}$ & 0.123 & & & & 0.096 & & & & 0.110 & & & & 0.114 & & & & 0.085 & & & & 0.114 & & & \\
\hline & 4102 & & & & 7778 & & & & 1718 & & & & 1430 & & & & 4657 & & & & 1408 & & & \\
\hline
\end{tabular}

Note: Table entries are the results of multiple regression analyses prediction of dimensions of political support. $\beta$ - standardized regression coefficients; $b$ - unstandardized regression coefficients; $p-p$-value (if $<0.050$ the variable is significant to the model). Missing values were replaced by mean. Source: European Social Survey $(2$

Table 2. Social and institutional individual-level determinants

\begin{tabular}{|c|c|c|c|c|c|c|c|c|c|c|c|c|c|c|c|c|c|c|c|c|c|c|c|c|}
\hline & \multicolumn{4}{|c|}{ Northern Europe } & \multicolumn{4}{|c|}{$\begin{array}{l}\text { Western and Central } \\
\text { Europe }\end{array}$} & \multicolumn{4}{|c|}{ Britain-Ireland } & \multicolumn{4}{|c|}{ Southern Europe } & \multicolumn{4}{|c|}{ Eastern Europe } & \multicolumn{4}{|c|}{ Baltic States } \\
\hline & B & $\begin{array}{l}\text { S. } \\
\text { E. }\end{array}$ & $\mathrm{t}$ & $\mathrm{p}$ & B & $\begin{array}{l}S . \\
\text { E. } \\
\text { E. }\end{array}$ & $\mathrm{t}$ & $\mathrm{p}$ & B & $\begin{array}{l}\text { S. } \\
\text { E. }\end{array}$ & $\mathrm{t}$ & $p$ & B & $\begin{array}{l}\text { S. } \\
\text { E. }\end{array}$ & $\mathrm{t}$ & $p$ & B & $\begin{array}{l}\text { S. } \\
\text { E. }\end{array}$ & $\mathrm{t}$ & $p$ & B & $\begin{array}{l}\text { S. } \\
\text { E. }\end{array}$ & $\mathrm{t}$ & $\mathrm{p}$ \\
\hline $\begin{array}{l}\text { nder } \\
\text { ale) }\end{array}$ & .036 & .02 & $\begin{array}{r}1.74 \\
7\end{array}$ & $\begin{array}{c}.08 \\
1\end{array}$ & .001 & $\frac{.01}{5}$ & .039 & $\begin{array}{r}.96 \\
9\end{array}$ & .054 & $\begin{array}{l}.03 \\
3\end{array}$ & 1.61 & $\begin{array}{r}.10 \\
7\end{array}$ & .066 & $\begin{array}{l}.03 \\
6\end{array}$ & 1.84 & $\begin{array}{r}.06 \\
5\end{array}$ & .035 & .02 & 1.54 & $\begin{array}{r}12 \\
1\end{array}$ & $.010^{\circ}-(x)$ & .03 & 256 & $\begin{array}{r}79 \\
8\end{array}$ \\
\hline $\begin{array}{l}P \text { (in } \\
\mathrm{ars})\end{array}$ & .000 & $\begin{array}{r}.00 \\
1\end{array}$ & .056 & $\begin{array}{r}.95 \\
6\end{array}$ & .001 & .00 & 2.37 & .01 & .003 & .00 & 1.86 & $\begin{array}{r}.06 \\
3\end{array}$ & .003 & $\begin{array}{r}.00 \\
1\end{array}$ & 1.72 & $\begin{array}{r}.08 \\
6\end{array}$ & .001 & .00 & $\begin{array}{r}1.34 \\
6\end{array}$ & $\begin{array}{r}.17 \\
9\end{array}$ & .005 & $\begin{array}{r}.00 \\
2\end{array}$ & $\begin{array}{r}2.67 \\
5\end{array}$ & .00 \\
\hline scation & .038 & .00 & 6.36 & $.0 o$ & .029 & .oo & 6.16 & .00 & .055 & .01 & 5.66 & .oo & .017 & .01 & 1.69 & .09 & .037 & .00 & 4.44 & .oo & .026 & .01 & 2.17 & .03 \\
\hline $\begin{array}{l}\text { usehold } \\
\text { otal net } \\
\text { ome }\end{array}$ & .049 & $\begin{aligned} 6 \\
.01 \\
7\end{aligned}$ & $\begin{array}{r}4 \\
2.88 \\
2\end{array}$ & .00 & .070 & $\begin{array}{r}5 \\
.01 \\
1\end{array}$ & 6.19 & . & .023 & $\begin{array}{l}0 \\
.02 \\
3\end{array}$ & .992 & $\begin{array}{r}0 \\
.32 \\
1\end{array}$ & .018 & $\begin{array}{l}0 \\
.02 \\
5\end{array}$ & $.722^{6}$ & $\begin{array}{r}0 \\
47 \\
1\end{array}$ & .028 & $\begin{array}{l}8 \\
.01 \\
5\end{array}$ & $\begin{array}{r}1.83 \\
8\end{array}$ & $\begin{array}{l}00 \\
.06 \\
6\end{array}$ & .037 & $\begin{array}{r}2 \\
.02 \\
9\end{array}$ & 1.31 & $\begin{array}{r}0 \\
.18 \\
9\end{array}$ \\
\hline $\begin{array}{l}\text { bjective) } \\
\text { lour } \\
\text { lation } \\
\text { employe }\end{array}$ & .076 & .02 & $\begin{array}{r}2.66 \\
2\end{array}$ & $\begin{array}{r}.00 \\
8\end{array}$ & .013 & .01 & .679 & .49 & .063 & .04 & $\begin{array}{r}1.42 \\
1\end{array}$ & $\begin{array}{r}.15 \\
6\end{array}$ & .045 & $\begin{array}{r}.04 \\
0\end{array}$ & $\begin{array}{r}1.14 \\
5\end{array}$ & $\begin{array}{r}.25 \\
2\end{array}$ & .002 & $\begin{array}{r}.03 \\
0\end{array}$ & -.083 & $\begin{array}{r}.93 \\
4\end{array}$ & .080 & $\begin{array}{r}.05 \\
1\end{array}$ & $\begin{array}{r}1.56 \\
6\end{array}$ & .11 \\
\hline $\begin{array}{l}\text { rital } \\
\text { tus }\end{array}$ & .071 & .02 & $\begin{array}{r}3.02 \\
0\end{array}$ & $\begin{array}{r}.00 \\
3\end{array}$ & .015 & .01 & -.848 & $\begin{array}{r}.39 \\
6\end{array}$ & .019 & .03 & .485 & $\begin{array}{r}.62 \\
8\end{array}$ & .116 & .03 & $\begin{array}{r}3.00 \\
3\end{array}$ & $\begin{array}{r}.00 \\
3\end{array}$ & .002 & .02 & -.071 & .94 & .006 & $\begin{array}{l}.04 \\
1\end{array}$ & -.138 & .89 \\
\hline $\begin{array}{l}\text { arried) } \\
\text { eof } \\
\text { isehold }\end{array}$ & .021 & .01 & $\begin{array}{r}2.18 \\
1\end{array}$ & $\begin{array}{r}.02 \\
9\end{array}$ & $.002^{-}$ & $\begin{array}{r}.00 \\
7\end{array}$ & -.324 & $\begin{array}{r}.74 \\
6\end{array}$ & .006 & .01 & -.389 & $\begin{array}{r}.69 \\
8\end{array}$ & .018 & $\begin{array}{r}.01 \\
5\end{array}$ & 1.21 & $\begin{array}{r}.22 \\
7\end{array}$ & $.010^{\circ}$ & .01 & 1.05 & $\begin{array}{r}.29 \\
1\end{array}$ & .029 & .01 & $\begin{array}{r}1.75 \\
8\end{array}$ & $\begin{array}{r}.07 \\
9\end{array}$ \\
\hline & .150 & .04 & $\begin{array}{r}3.68 \\
1\end{array}$ & .00 & .098 & .02 & $\begin{array}{r}3.71 \\
8\end{array}$ & .00 & .141 & .06 & 2.22 & .02 & .053 & .07 & .743 & $\begin{array}{r}.45 \\
7\end{array}$ & .084 & .05 & $\begin{array}{r}1.42 \\
1\end{array}$ & $\begin{array}{r}.15 \\
5\end{array}$ & .062 & $\begin{array}{r}.06 \\
6\end{array}$ & -.940 & .34 \\
\hline minate & .149 & $\begin{array}{r}.04 \\
4\end{array}$ & 3.41 & $\begin{array}{c}.00 \\
1\end{array}$ & .141 & $\begin{array}{r}.03 \\
2\end{array}$ & 4.37 & .00 & .200 & $\begin{array}{c}.05 \\
1\end{array}$ & 3.90 &. .00 & .015 & $\begin{array}{r}.08 \\
5\end{array}$ & -.180 & $\begin{array}{r}85 \\
8\end{array}$ & .133 & .04 & 2.69 & \begin{tabular}{r|}
.00 \\
7
\end{tabular} & 209 & .08 & 2.42 & .01 \\
\hline $\begin{array}{l}\text { roup } \\
\text { ong to } \\
\text { tority }\end{array}$ & $.079^{\circ}$ & .06 & 1.23 & .21 & .079 & .04 & 1.93 & $\begin{array}{r}.05 \\
3\end{array}$ & .048 & .08 & .590 & $\begin{array}{r}.55 \\
5\end{array}$ & .051 & $\begin{array}{r}.10 \\
9\end{array}$ & -.470 & $\begin{array}{r}.63 \\
9\end{array}$ & .003 & .07 & $\begin{array}{r}9 \\
-.044\end{array}$ & $\begin{array}{r}.96 \\
5\end{array}$ & .031 & .07 & $\begin{array}{r}3^{3} \\
.440\end{array}$ & .66 \\
\hline $\begin{array}{l}\text { nic group } \\
\text { ong a } \\
\text { gion }\end{array}$ & .073 & .17 & $-.431^{6}$ & $\begin{array}{r}.66 \\
6\end{array}$ & .028 & $\begin{array}{r}14 \\
1\end{array}$ & -.202 & .84 & .341 & $\begin{array}{r}.23 \\
4\end{array}$ & 1.45 & .14 & 299 & .37 & .796 & $\begin{array}{r}.42 \\
6\end{array}$ & .308 & .27 & 1.11 & $\begin{array}{r}.26 \\
5\end{array}$ & .180 & $\begin{array}{r}.27 \\
7\end{array}$ & -.651 & .51 \\
\hline $\begin{array}{l}\text { ligion } \\
\text { ligondance } \\
\text { andand }\end{array}$ & .007 & .01 & .614 & $\begin{array}{r}.53 \\
9\end{array}$ & .027 & .00 & $\begin{array}{r}3.96 \\
7\end{array}$ & .00 & .021 & .01 & $\begin{array}{r}1.38 \\
1\end{array}$ & $\begin{array}{r}.16 \\
7\end{array}$ & $.010^{\circ}$ & .01 & -.657 & $\begin{array}{r}.51 \\
1\end{array}$ & .015 & .01 & 1.43 & $\begin{array}{r}.15 \\
2\end{array}$ & .022 & .02 & 1.09 & .27 \\
\hline iversalis & .016 & .00 & 1.65 & .09 & .017 & $\begin{array}{l}.00 \\
8\end{array}$ & 2.20 & .02 & .000 & .01 & -.001 & $\begin{array}{r}.99 \\
9\end{array}$ & .047 & .02 & 2.06 & $\begin{array}{l}.03 \\
9\end{array}$ & .028 & .01 & $\begin{array}{r}2.50 \\
7\end{array}$ & .01 & .017 & .01 & -.941 & $\begin{array}{r}.34 \\
7\end{array}$ \\
\hline ividualis & $.001^{-}$ & $\begin{array}{r}.01 \\
1\end{array}$ & -.075 & .94 & .004 & $\begin{array}{l}.00 \\
8\end{array}$ & .482 & $\begin{array}{r}.63 \\
0\end{array}$ & .017 & .01 & -.934 & $\begin{array}{r}.35 \\
0\end{array}$ & .025 & .01 & $\begin{array}{r}1.35 \\
3\end{array}$ & $\begin{array}{r}.17 \\
6\end{array}$ & .053 & .01 & 4.24 & $\begin{array}{r}.00 \\
0\end{array}$ & .048 & $\begin{array}{r}.02 \\
1\end{array}$ & 2.32 & .02 \\
\hline donism & $.019^{\circ}$ & .01 & 1.97 & $\begin{array}{r}.04 \\
8\end{array}$ & .041 & .00 & 5.39 & .00 & .023 & .01 & 1.47 & $\begin{array}{r}.14 \\
0\end{array}$ & .036 & .01 & 2.08 & $\begin{array}{r}.03 \\
7\end{array}$ & .041 & .01 & 3.86 & .00 & $.050^{\circ}$ & $\begin{array}{r}.02 \\
0\end{array}$ & 2.46 & .01 \\
\hline $\begin{array}{l}\text { st- } \\
\text { terialism }\end{array}$ & .092 & .01 & 5.77 & .00 & .059 & .01 & 5.81 & .00 & .003 & $\begin{array}{r}.02 \\
5\end{array}$ & $\begin{array}{r}-.104 \\
\end{array}$ & .91 & .020 & .02 & $\begin{array}{r}-.789 \\
-.78\end{array}$ & $\begin{array}{r}.43 \\
0\end{array}$ & .025 & .01 & 1.79 & $\begin{array}{r}.07 \\
3\end{array}$ & .008 & .02 & $\begin{array}{r}9 \\
.304\end{array}$ & .76 \\
\hline $\begin{array}{l}\text { IRadio/N } \\
s\end{array}$ & .037 & .00 & 4.26 & .00 & .010 & .00 & 1.65 & $\begin{array}{r}.09 \\
8\end{array}$ & .021 & .01 & 1.53 & $\begin{array}{r}.12 \\
4\end{array}$ & .020 & .01 & 1.28 & $\begin{array}{r}.19 \\
8\end{array}$ & .007 & .00 & $\begin{array}{r}6 \\
-.761\end{array}$ & .44 & $.041^{-1}$ & .01 & 2.68 & .00 \\
\hline 'sonal & .023 & .00 & $\begin{array}{r}4.28 \\
3\end{array}$ & .00 & $.0 s 7$ & .00 & $\begin{array}{r}4 \\
1.99 \\
1\end{array}$ & $\begin{array}{r}.04 \\
7\end{array}$ & .017 & .00 & $\begin{array}{r}8 \\
2.31 \\
9\end{array}$ & $\begin{array}{r}.02 \\
1\end{array}$ & .013 & .00 & $\begin{array}{r}1.52 \\
2\end{array}$ & $\begin{array}{r}.12 \\
8\end{array}$ & .001 & .00 & -.227 & $\begin{array}{r}82 \\
0\end{array}$ & $.005^{\circ}$ & .01 & $\begin{array}{r}4 \\
-.491\end{array}$ & .62 \\
\hline $\begin{array}{l}\text { ernet } \\
\text { itical } \\
\text { 'ernment } \\
\text { formance }\end{array}$ & .083 & .00 & $\begin{array}{r}16.0 \\
24\end{array}$ & .00 & .125 & .00 & $\begin{array}{r}32.6 \\
51\end{array}$ & .00 & .099 & .00 & $\begin{array}{r}12.0 \\
46\end{array}$ & .00 & .091 & .01 & $\begin{array}{r}9.12 \\
2\end{array}$ & $\begin{array}{c}.00 \\
0\end{array}$ & .149 & .00 & $\begin{array}{r}26.6 \\
15\end{array}$ & .00 & $.185^{\circ}$ & .01 & $\begin{array}{r}16.1 \\
51\end{array}$ & .00 \\
\hline $\begin{array}{l}\text { Jnomical } \\
\text { 'ernment } \\
\text { formance }\end{array}$ & $.004^{-1}$ & .00 & -.743 & $\begin{array}{r}.45 \\
8\end{array}$ & .056 & .00 & $\begin{array}{r}13.6 \\
50\end{array}$ & .00 & .078 & .01 & $\begin{array}{r}8.19 \\
4\end{array}$ & .00 & .076 & .01 & $\begin{array}{r}6.80 \\
8\end{array}$ & .00 & .042 & .00 & $\begin{array}{r}6.43 \\
7\end{array}$ & .00 & .037 & .01 & $\begin{array}{r}3.29 \\
2\end{array}$ & .00 \\
\hline $\begin{array}{l}\text { Ifare } \\
\text { ite } \\
\text { formance }\end{array}$ & .134 & .00 & $\begin{array}{r}20.9 \\
08\end{array}$ & $\begin{array}{r}.00 \\
0\end{array}$ & .077 & .00 & $\begin{array}{r}18.6 \\
28\end{array}$ & .00 & .096 & .01 & $\begin{array}{r}9.87 \\
1\end{array}$ & $\begin{array}{l}.00 \\
0\end{array}$ & .115 & .01 & $\begin{array}{r}11.0 \\
31\end{array}$ & .00 & .085 & .00 & $\begin{array}{r}14.9 \\
13\end{array}$ & .00 & .055 & .01 & $\begin{array}{r}4.80 \\
5\end{array}$ & .00 \\
\hline usted $\mathrm{R}^{2}$ & $\begin{array}{r}0.31 \\
9 . \\
0.31 \\
4 \\
\end{array}$ & & & & $\begin{array}{r}0.40 \\
0 \\
0.39 \\
7 \\
\end{array}$ & & & & $\begin{array}{r}0.38 \\
6 \\
0.37 \\
5 \\
\end{array}$ & & & & $\begin{array}{r}0.33 \\
7 \\
0.32 \\
3 \\
\end{array}$ & & & & $\begin{array}{r}0.34 \\
3 \\
0.33 \\
8 \\
\end{array}$ & & & & $\begin{array}{r}0.44 \\
3 \\
0.43 \\
2 \\
2\end{array}$ & & & \\
\hline & $\begin{array}{r}4 \\
012\end{array}$ & & & & \begin{tabular}{|l|}
778 \\
\end{tabular} & & & & \begin{tabular}{|l|l}
1 \\
718
\end{tabular} & & & & $\begin{array}{r}1 \\
430 \\
\end{array}$ & & & & $\begin{array}{r}44 \\
657\end{array}$ & & & & $\begin{array}{r}1 \\
408\end{array}$ & & & \\
\hline
\end{tabular}


Note: Table entries are the results of multiple regression analyses prediction of dimensions of political support. $\beta$ - standardized regression coefficients; $b$ - unstandardized regression coefficients; $p$ - $p$-value (if $<0.050$ the variable is significant to the model). Missing values were replaced by mean. Source: European Social Survey (2010).

Table 3. Civic and political awareness individual-level determinants

\begin{tabular}{|c|c|c|c|c|c|c|c|c|c|c|c|c|c|c|c|c|c|c|c|c|c|c|c|c|}
\hline & \multicolumn{4}{|c|}{ Northern Europe } & \multicolumn{4}{|c|}{ Western and Central } & \multicolumn{4}{|c|}{ Britain-Ireland } & \multicolumn{4}{|c|}{ Southern Europe } & \multicolumn{4}{|c|}{ Eastern Europe } & \multicolumn{4}{|c|}{ Baltic States } \\
\hline & B & S. & $\mathrm{t}$ & $\mathrm{p}$ & B & $\mathrm{S}$. & $t$ & $\mathrm{p}$ & B & S. & $\mathrm{t}$ & $p$ & B & $\mathrm{S}$. & $\mathrm{t}$ & $p$ & B & S. & $\mathrm{t}$ & $p$ & $B$ & S. & $\mathrm{t}$ & $p$ \\
\hline & .24 & 02 & 8.41 & .00 & .23 & .02 & 11.4 & .00 & .31 & .04 & 6.69 & .00 & .26 & .04 & 5.87 & .00 & .34 & .02 & 13.2 & .00 & .25 & .04 & 5.22 & .00 \\
\hline & 1 & .00 & 11.1 & .00 & 0 & .00 & 8.79 & .00 & .00 & .00 & & .00 & Do & .00 & 45 & 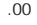 & 0 & .00 & 5.57 & 00 & .00 & .00 & -.110 & .91 \\
\hline ion & .06 & .00 & 7.43 & .00 & .05 & .00 & 9.02 & .00 & .07 & .01 & 5.47 & .00 & .04 & .01 & 3.21 & .00 & .04 & .01 & 4.11 & .00 & .01 & .01 & .985 & .32 \\
\hline hold & 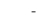 & $.02 \overline{2}$ & -.786 & .43 & .06 & .01 & 4.44 & .000 & .02 & .03 & .735 & $.4 \overline{6}$ & .01 & $.0 \overline{3}$ & .612 & .54 & .00 & .00 & 1.45 & $.1 \overline{4}$ & $=$ & .01 & -.217 & .82 \\
\hline iur & - & .04 & - & .00 & - & .02 & - & .00 & - & .06 & - & .04 & - & .04 & - & .01 & 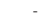 & .03 & 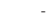 & .00 & - & .06 & -.699 & .48 \\
\hline lal & - & .03 & - & .10 & - & .02 & 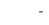 & .11 & .04 & .05 & .814 & .41 & - & .04 & - & .3 & 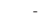 & .02 & 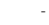 & .16 & .05 & .05 & 12 & .26 \\
\hline of & - & .01 & - & .10 & - & .01 & 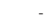 & .25 & - & .02 & - & .00 & - & .01 & -.669 & .50 & - & .01 & -.336 & .73 & - & .02 & - & .10 \\
\hline in & .05 & .05 & .932 & .35 & .00 & .03 & -.007 & .99 & - & .09 & - & .23 & - & .08 & & .17 & .02 & .06 & .293 & .77 & .10 & .08 & 1.33 & .18 \\
\hline er of & .06 & .06 & 1.11 & .26 & .16 & .04 & 3.80 & .00 & - & .07 & -.252 & .80 & .19 & .10 & 1.80 & .07 & . 12 & .05 & 2.17 & .03 & .05 & .10 & .496 & .62 \\
\hline to & .28 & .09 & 3.10 & .00 & - & .05 & -.055 & .95 & .15 & .11 & 1.34 & .1 & .15 & .13 & 1.15 & .2 & .04 & .08 & .570 & .5 & .20 & .08 & 2.40 & .01 \\
\hline$a$ & - & .24 & -.108 & $.9 \overline{1}$ & - & .19 & -.171 & $.8 \overline{6}$ & .72 & $.3 \overline{3}$ & 2.17 & $.0 \overline{3}$ & $.6 \overline{2}$ & .46 & $1.3 \overline{4}$ & .08 & - & .32 & -.885 & .37 & - & .34 & - & .25 \\
\hline & .01 & .01 & .869 & .38 &.$\overline{0} 0$ & $.00 \overline{0}$ & .173 & .86 & - & .02 & -.245 & .80 & - & .01 & -.852 & .39 & (00 & .01 & .216 & .82 & - & $.0 \overline{2}$ & -.104 & .91 \\
\hline salis & 12 & .01 & 9.01 & .00 & . 18 & .01 & 17.0 & .00 & .14 & .02 & 6.24 & .00 & .27 & .02 & 9.48 & .00 & .24 & .01 & 18.1 & .00 & .16 & .02 & 7.48 & .00 \\
\hline talis & $=$ & $.0 \overline{1}$ & & .01 & - & .01 & & .00 & $=$ & $.0 \overline{2}$ & - & .00 & $.0 \overline{1}$ & $.0 \overline{2}$ & .601 & .54 & $=$ & $.0 \overline{1}$ & & .00 & $=$ & $.0 \overline{2}$ & $=$ & .00 \\
\hline Jnism & - & $.0 \overline{1}$ & - & $.00 \overline{0}$ & $=$ & .01 & 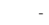 & $.0 \overline{0}$ & - & .02 & - & .00 & : & $.0 \overline{2}$ & - & $.0 \overline{0}$ & - & .01 & & .00 & - & $.02 \overline{2}$ & - & .10 \\
\hline 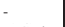 & 10 & .02 & .051 & .05 & .06 & $.0 \overline{1}$ & 4.69 & .00 & .06 & $.0 \overline{3}$ & $\overline{1} . \overline{8} 1$ & .07 & .00 & $.0 \overline{3}$ & .293 & $.7 \overline{7}$ & .01 & $.0 \overline{1}$ & $1.0 \overline{8}$ & .27 & .06 & .03 & 1.96 & .05 \\
\hline tio/N & .26 & .01 & 21.6 & .00 & .20 & .00 & 24.3 & .00 & .22 & .01 & 11.8 & .00 & .21 & .01 & 10.8 & .00 & . 15 & .01 & 15.1 & .00 & .28 & $.0 \overline{1}$ & 15.4 & .00 \\
\hline nal & .21 & .00 & 1.43 & .05 & .02 & .00 & 4.68 & .00 & .03 & .01 & 2.96 & .00 & .00 & .01 & .901 & .36 & & .00 & -.519 & .60 & .01 & .01 & 1.23 & .21 \\
\hline & 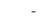 & .00 & -.115 & .10 & 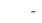 & .00 & & .00 & - & .01 & . & .00 & - & .01 & -.844 & .00 & - & .00 & & .04 & - & .01 & - & .08 \\
\hline 1omice & - & .00 & & .06 & 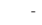 & .00 & & .00 & - & .01 & -.563 & .57 & - & .01 & & .02 & - & .00 & -.422 & .00 & - & .01 & - & .00 \\
\hline \multirow[t]{2}{*}{ are } & .01 & .00 & 1.44 & .14 & .03 & .00 & 2.49 & .01 & .00 & .01 & .540 & .58 & .21 & .01 & 1.27 & .00 & .14 & .00 & 2.63 & .00 & .04 & .01 & 3.04 & .12 \\
\hline & 0.2 & & & & 0.2 & & & & 0.2 & & & & 0.2 & & & & 0.2 & & & & 0.2 & & & \\
\hline \multirow[t]{2}{*}{ sted } & 0.2 & & & & 0.2 & & & & 0.2 & & & & 0.2 & & & & 0.1 & & & & 0.2 & & & \\
\hline & 12 & & & & $\begin{array}{l}7 \\
778\end{array}$ & & & & $\begin{array}{l}1 \\
718\end{array}$ & & & & 430 & & & & $\begin{array}{l}4 \\
657\end{array}$ & & & & $\begin{array}{l}1 \\
408\end{array}$ & & & \\
\hline
\end{tabular}

Note: Table entries are the results of multiple regression analyses prediction of dimensions of political support. $\beta$ - standardized regression coefficients; $b$ - unstandardized regression coefficients; $p-p$-value (if $<0.050$ the variable is significant to the model). Missing values were replaced by mean. Source: European Social Survey (2010).

Table 4. Social cohesion and sense of community individual-level determinants

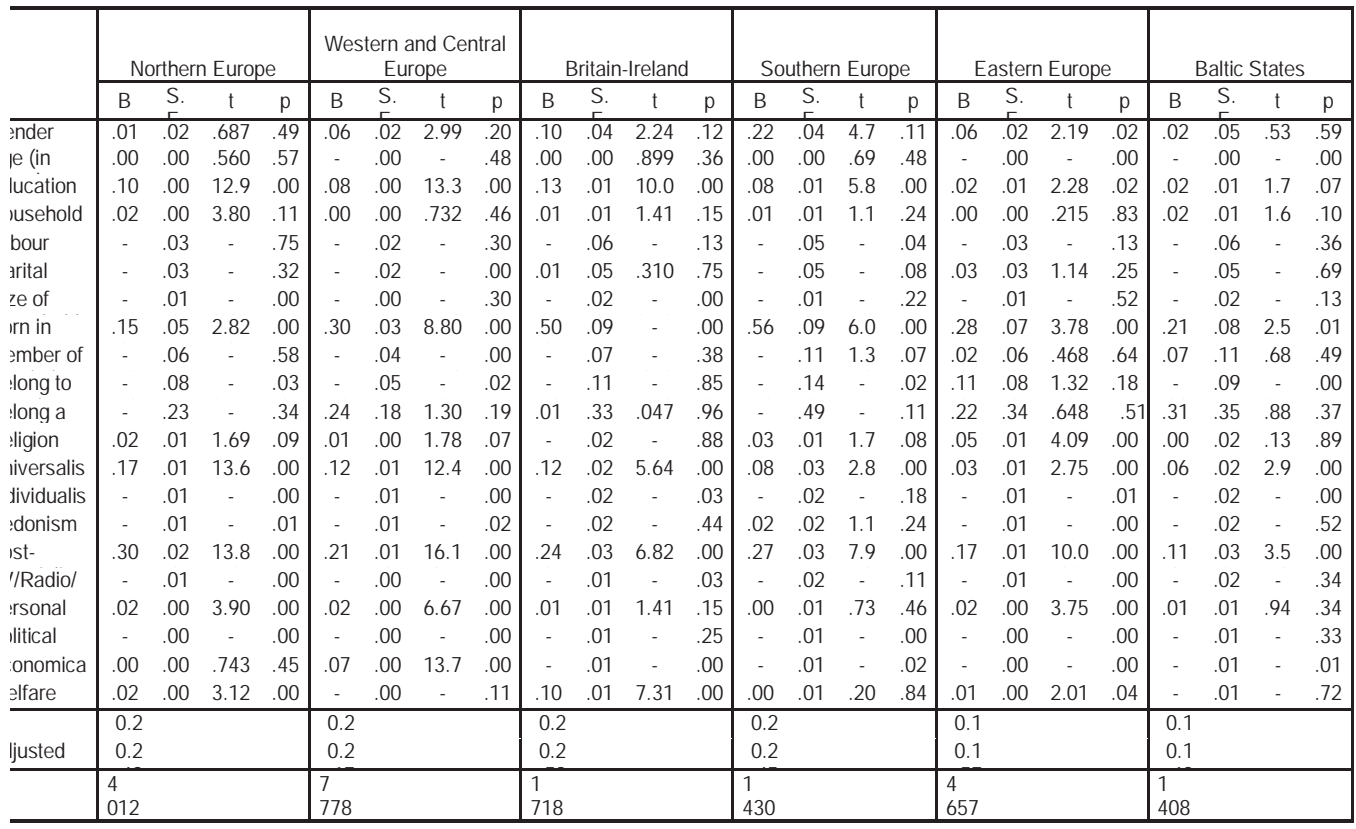

Note: Table entries are the results of multiple regression analyses prediction of dimensions of political support. $\beta$ - standardized regression coefficients; $b$ - unstandardized regression coefficients; $p$ - $p$-value (if $<0.050$ the variable is significant to the model). Missing values were replaced by mean. Source: European Social Survey 2010. 


\section{Appendix C}

Table 1. Social networks determinants (multi-level analysis)

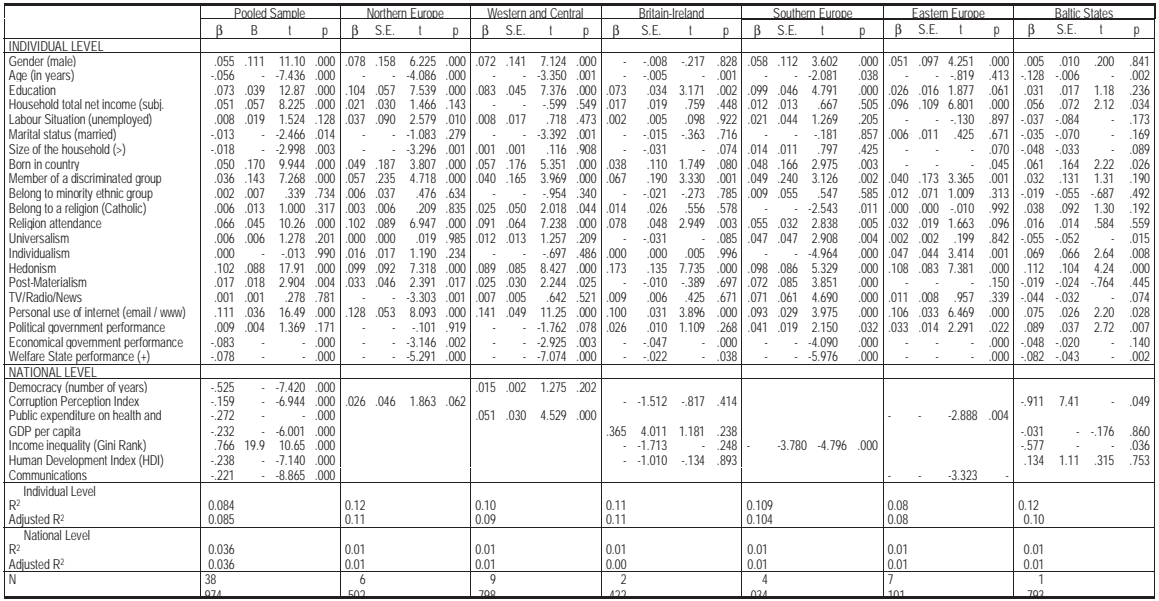

Table 2. Social and institutional trust determinants (multi-level analysis)

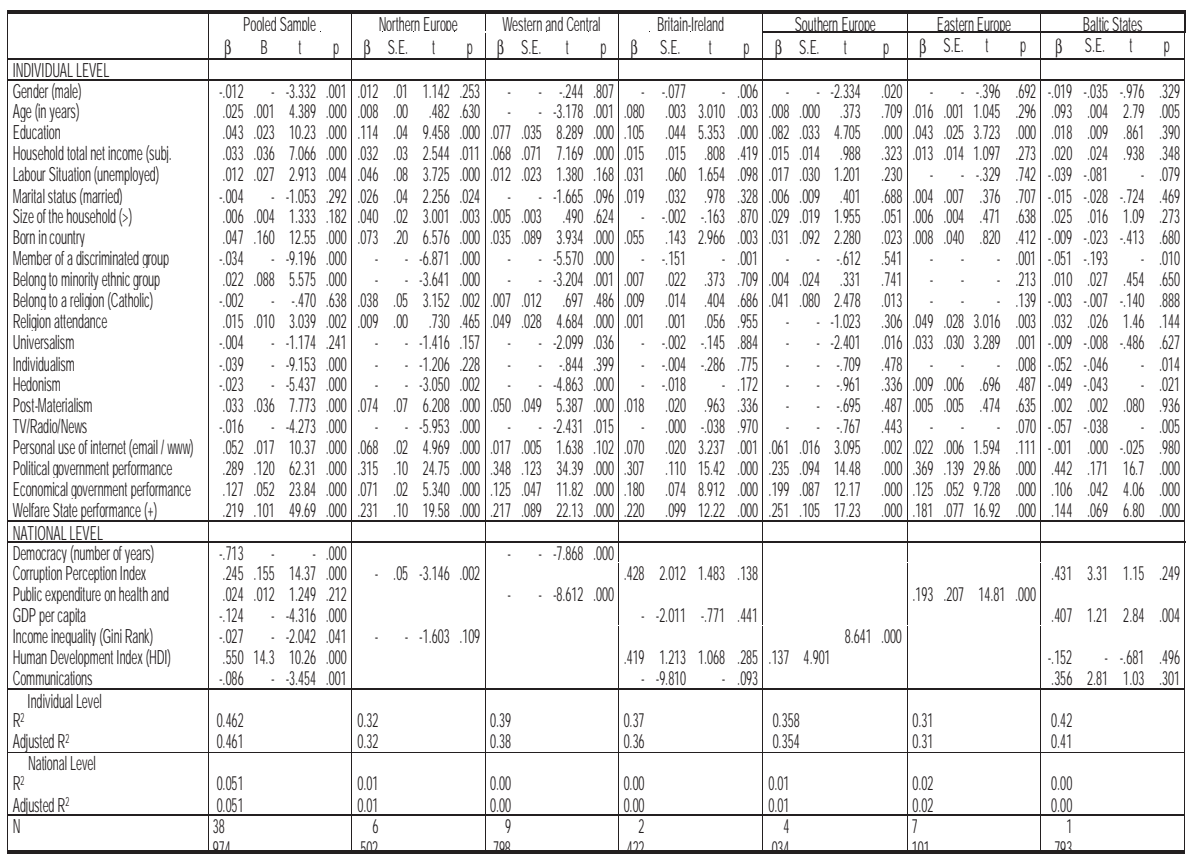

Note: Table entries are the results of multiple regression analyses prediction of dimensions of political support. $\beta$ - standardized regression coefficients; $b$ - unstandardized regression coefficients; $p-p$-value (if $<0.050$ the variable is significant to the model). Missing values were replaced by mean. Source: European Social Survey 2010. 
Table 3. Civic and political awareness determinants (multi-level analysis)

\begin{tabular}{|c|c|c|c|c|c|c|c|c|c|c|c|c|c|c|c|c|c|c|c|c|c|}
\hline \multirow[b]{3}{*}{ NDIVIDU } & \multicolumn{3}{|c|}{ Pooled Sample } & \multicolumn{2}{|c|}{ Northem Eurooe } & \multicolumn{3}{|c|}{ Western and Central } & \multicolumn{3}{|c|}{ Bititain-releland } & \multicolumn{3}{|c|}{ Southem Europe } & \multicolumn{3}{|c|}{ Eastern Europe } & \multicolumn{4}{|c|}{ Balic States } \\
\hline & $\begin{array}{ll}\beta & B \\
\end{array}$ & t & p & $\beta$ S.E. & $t \quad p$ & $\begin{array}{ll}\beta & \text { S.E. }\end{array}$ & $t \quad p$ & p & $\begin{array}{ll}\beta & S . E . \\
\beta\end{array}$ & t & p & $\beta$ S.E. & t & $p$ & $\begin{array}{lll}\beta & \text { S.E } \\
\end{array}$ & E. $t$ & $p$ & $\beta$ & S.E. & $\mathrm{t}$ & \\
\hline & & & & & & & & & & & & & & & & & & & & & \\
\hline & 73 & 3 & .000 & $.24 \quad .25$ & 511.07 .00 & $.120 \quad 234$ & 12.84 .00 & & 163 & 8.479 & .0 & 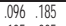 & 6.947 & & & 16.38 & 8.000 & & & & \\
\hline & & $\begin{array}{lll}8 & 20.65 & 0 \\
1 & 18.14 & 0\end{array}$ & & & & $\begin{array}{l}.134 .007 \\
125 \\
.068\end{array}$ & $\begin{array}{l}9.668 .00 \\
1204.00\end{array}$ & 000.1 .1$. & $\begin{array}{ll}.113 & .006 \\
122 & .064\end{array}$ & 3.765 & .000 . & $\begin{array}{l}.105 .005 \\
.090 \quad 042\end{array}$ & $\begin{array}{l}5.070 \\
5113\end{array}$ & .000. & & & 8.000 & & & .796 & 36 \\
\hline total netine & & 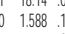 & .112 & $\begin{array}{l}.030 \quad .04 \\
.04\end{array}$ & & 043.054 & $\begin{array}{l}42.042 .00 \\
4.082 .00\end{array}$ & 000. & . $.005 . .006$ & .241 & .809 & 年 051.030 & $\begin{array}{l}5.115 \\
3.506\end{array}$ & .000 & & & 7.836 & & & & \\
\hline & & & & & & & & & & & . 051 & & -1.478 & .139 & & 4.211 & & & .038 . & & \\
\hline & & -4.663 .0 & .000 & . & -2.537 .01 & & -4.687 .00 & & .008 $\quad .015$ & 340 & .734 & & .702 & .483 & & .873 & 3.383 & 032 & .062 & 1.34 & \\
\hline & & -3.941 .0 & .000 & & 2.2308 .02 & & .924 .35 & & $\begin{array}{c}-.062 \\
.006\end{array}$ & & .001 & & -1.769 & .077 & & .266 & 60.206. & .063. & .043 & & \\
\hline & & -5.012 & .000 & .010 .03 & $\begin{array}{ll}3.872 .38 \\
300\end{array}$ & & .551 .58 & & .065 & .958 & .338 & & .970 & .332 & .006 .033 & $032 \quad .565$ & 55.572 & .002 & .006 & .092 & \\
\hline & 101 026 & 15.513. & .000 & .025 .10 & 2.293 .02 & .030 .125 & 3.253 .00 & & . 012 & -196 & .845 & . 025 & 1.850 & .064 . & . 038.16. & $161 \quad 3.385$ & 35.001 & & & 100 & \\
\hline & $\begin{array}{ll}.018 .073 & .013 \\
.013\end{array}$ & $\begin{array}{ll}3 & 3.673 \\
- & -2.283 \\
.\end{array}$ & .000 & . 040.24 & $\begin{array}{l}43.506 .00 \\
.1 .710 .08 \\
.08\end{array}$ & & $\begin{array}{r}.680 .49 \\
.3025 .00\end{array}$ & 197.0 .0 & $\begin{array}{l}.052 . .206 \\
.081\end{array}$ & 2.495 & .013 & $\begin{array}{l}.027 .173 \\
.012 .027\end{array}$ & $\begin{array}{r}2.004 \\
.711\end{array}$ & $\begin{array}{l}.045 \\
.477\end{array}$ & .011 .06 & $\begin{array}{ll}066 & 1.010 \\
-1.329\end{array}$ & 29.313 & 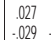 & $\begin{array}{l}.077 \\
.069\end{array}$ & 1.06. & 88 \\
\hline & & -2.646 & . 008 & . 01 & 1.368 .17 & .004 .003 & .308 .75 & 258.0 & .004 .003 & .176 & .860 & & -3.404 & .001 & &. .526 & & .023 & & .941 & \\
\hline & & & .000 & & -.00 & & & & . & & .000 & & & .000 & & & & .208 & & & \\
\hline & & & & . 001.00 & . 087.93 & $\cdot$ & -5.462 .00 & & & & .000 & & -4.996 & .000 & & -6.159 & & .094 & & & \\
\hline & & & .000 & & & & & & 558 & & .002 & & -8.577 & .000 & & & & 79. & 73 & & \\
\hline & 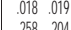 & 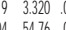 & .001 & $\begin{array}{ll}.024 \quad .03 \\
221\end{array}$ & $\begin{array}{l}31.938 .05 \\
60778.00\end{array}$ & .038 .045 & 3.675 .00 & & $\begin{array}{l}.029 \\
.040 \\
.236\end{array}$ & 1.377 & . 168 & . 023 & 1.210 & .226. & .025 .028 & & & & & 2.06 & \\
\hline & .258. 204 & $\begin{array}{ll}4 \quad 54.76 \\
\end{array}$ & .000 & .321 .26 & 627.78 .00 & 2.259 .200 & 27.18 & & $.223 . .186$ & 11.66 & .000 & .252 .217 & 19.40 & .000 & .191 .14 & 141 & & & & 16.3 & \\
\hline & .012. 004 & $\begin{array}{lll}4 & 1.934\end{array}$ & .053 & . $020 \quad .00$ & 1.400 .16 & $2.034 \quad .012$ & 2.915 .00 & & .053 .019 & 2.177 & .030 & 年. 032.010 & 1.593 & .1111. & & 001.125 & & .064 & .022 & 2.04 & \\
\hline & .031. 013 & 135.376 & .000 & & $\begin{array}{c}-191.84 \\
5\end{array}$ & $\begin{array}{l}3.024 .010 \\
.077\end{array}$ & 2.087 .03 & & .091 .040 & 4.026 & .000 & .031. 014 & 1.851 & .064 . & .030. 013 & $\begin{array}{ll}012 \quad 2.233 \\
.64\end{array}$ & & .048 & .020 & 1.60 & \\
\hline & .028 .011 & $\begin{array}{lll}11 & 4.150 \\
-8.845 & 0\end{array}$ & .000 & .007 .00 & $\begin{array}{r}5.513 .60 \\
0.324 .48\end{array}$ & 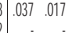 & 3.141 .00 & & .001 .001 & .044 & .965 & .042. 022 & 2.556 & .011 & & $\therefore .564$ & 4. & .056 . & .017 & & \\
\hline & & & & & & & & & & & & & & & & & & & & & \\
\hline & & & & & & .048. 006 & 4.446 .00 & & & & & & & & & & & & & & \\
\hline & & 8 & & & .194 .84 & & & & 1699.911 & .518 & .605 & & & & & & & .663 & 5.31 & & \\
\hline 'per capita & & $\begin{array}{c}-3.869 \\
-6.223 . \\
-6.9\end{array}$ & & & & & & & $450 \quad 5.611$ & 1.522 & .128 & & & & & & & .222 & & & \\
\hline & $\begin{array}{l}.167 .024 \\
.12\end{array}$ & 249 & .000 & $.005 \quad .00$ & .335 .73 & & & & & & & & 19.03 & & & & & & & & \\
\hline & $\begin{array}{l}.3128 .14 \\
.121 .012\end{array}$ & 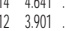 & . & & & & & & . & 920 & .351 & 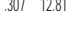 & & & & & & . .871 & & 2.22 & \\
\hline \begin{tabular}{|l}
$R^{2}$ \\
Individual Level
\end{tabular} & & & & 0.28 & & 0.20 & & & & & & & & & & & & & & & \\
\hline & & & & & & & & & & & & & & & & & & & & & \\
\hline $\mathrm{R}^{2}$ National Level & & & & 0.01 & & 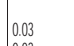 & & & 0.01 & & & & & & & & & & & & \\
\hline & 38 & & & 6 & & & & & & & & & & & & & & & & & \\
\hline & प्रan & & & (5) & & & & & & & & & & & & & & & & & \\
\hline
\end{tabular}

Note: Table entries are the results of multiple regression analyses prediction of dimensions of political support. $\beta$ - standardized regression coefficients; $b$ - unstandardized regression coefficients; $p$ - $p$-value (if $<0.050$ the variable is significant to the model). Missing values were replaced by mean. Source: European Social Survey 2010.

Table 4. Social cohesion and sense of community determinants (multi-level analysis)

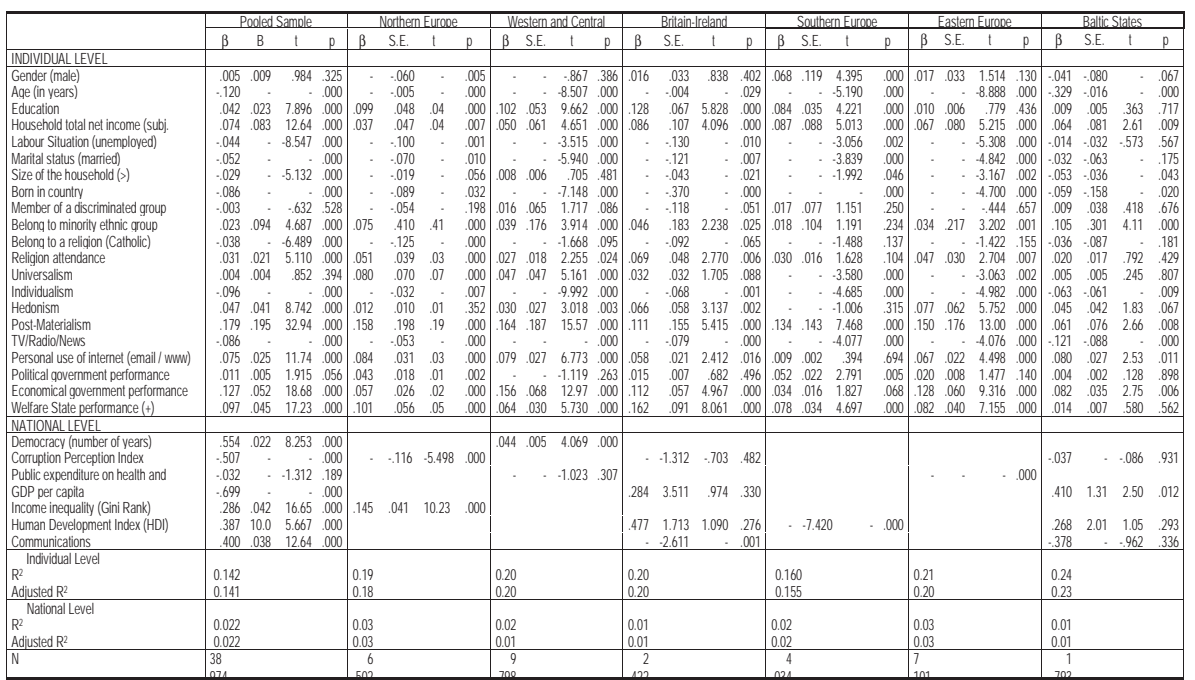

Note: Table entries are the results of multiple regression analyses prediction of dimensions of political support. $\beta$ - standardized regression coefficients; $b$ - unstandardized regression coefficients; $p-p$-value (if $<0.050$ the variable is significant to the model). Missing values were replaced by mean. Source: European Social Survey 2010. 


\section{Appendix D}

\begin{tabular}{|c|c|}
\hline Individual determinants of the social capital & Operationalization \\
\hline \multicolumn{2}{|l|}{ Block 1} \\
\hline Gender & 0: Male; 1: Female \\
\hline Age & (Date of birth) \\
\hline Education & (The highest level of education successfully completed) \\
\hline Household 's total net income (subjective dimension) & $\begin{array}{l}\text { Which of the descriptions on this card comes closest to how you feel } \\
\text { about your household's income nowadays? } \\
\text { 1= Finding it very difficult on present income } \\
2=\text { Finding it difficult on present income } \\
3=\text { Coping on present income } \\
4=\text { Living comfortably on present income }\end{array}$ \\
\hline Labour situation & $\begin{array}{l}\text { Thinking just of the last } 3 \text { years, what was the longest period in } \\
\text { months, if any, that you were continuously unemployed and seeking } \\
\text { work? }\end{array}$ \\
\hline Marital status & 0: Husband/wife/partner; 1: Other situations \\
\hline Size of household & $\begin{array}{l}\text { Including yourself, how many people }- \text { including children - live here } \\
\text { regularly as members of this household? }\end{array}$ \\
\hline Born in country & $\begin{array}{l}\text { Are you a citizen of [country]? } \\
\text { 0: Yes; 1: No }\end{array}$ \\
\hline Member of discriminated group & $\begin{array}{l}\text { Would you describe yourself as being a member of a group that is } \\
\text { discriminated against in this country? } \\
0 \text { : Yes; } 1 \text { : No }\end{array}$ \\
\hline Belong to minority ethnic group & $\begin{array}{l}\text { Do you belong to a minority ethnic group in [country]? } \\
0 \text { : Yes; } 1 \text { : No }\end{array}$ \\
\hline \multicolumn{2}{|l|}{ Block 2} \\
\hline Belong a religion & $\begin{array}{l}\text { Do you consider yourself as belonging to any particular religion or } \\
\text { denomination? } \\
\text { 0: Yes (Catholic); 1:No (other religions or denominations) }\end{array}$ \\
\hline Religion attendance & $\begin{array}{l}\text { Apart from special occasions such as weddings and funerals, about } \\
\text { how often do you attend religious services nowadays? } \\
1=\text { Never } \\
2=\text { Less often } \\
3=\text { Only on special holy days } \\
4=\text { At least once a month } \\
5=\text { Once a week } \\
6=\text { More than once a week }\end{array}$ \\
\hline Universalism & $\begin{array}{l}\text { H- Heren we briefly describe some people. Please read each description } \\
\text { and tick the box on each line that shows how much each person is or } \\
\text { is not like you. } \\
\text { He/she thinks it is important that every person in the world should be } \\
\text { treated equally. He/she believes everyone should have equal } \\
\text { opportunities in life. } \\
1=\text { Very much like me } \\
2=\text { Like me } \\
3=\text { Somewhat like me } \\
4=\text { A little like me } \\
5=\text { Not like me } \\
6=\text { Not like me at all }\end{array}$ \\
\hline
\end{tabular}


APPENDIX D \begin{tabular}{l} 
National determinants of the social capital \\
\hline POLITICAL NATIONAL-LEVEL INDICATORS
\end{tabular}

Democracy (years)

Corruption Perception Index

The CPI ranks countries/territories based on how corrupt their public sector is perceived to be. It is a composite index, a combination of polls, drawing on corruption-related data collected by a variety of reputable institutions. The CP reflects the views of observers from around the world, including experts living and working in the countries/territories evaluate. SOURCE: Transparency International.

The Welfare State is a "concept of government in which the state plays a key role in the protection and promotion of the economic and social well being of its citizens. It is based on the principles of equality of opportunity, equitable distribution of wealth, and public responsibility for those unable to avail themselves of the minimal provisions for a good life. The general term may cover a variety of economic and social policies.

SOURCE: The OECD Social Expenditure Database has been developed in order to serve a growing need for indicators of social policy. It includes reliable and to serve a growing need for indicators of social policy. It includes reliable and private social expenditure at government level. This database provides a unique tool for monitoring trends in aggregate social expenditure and analysing changes in its composition. The main social policy areas are in this study as follows: health, education, and old age.

\section{SOCIAL AND CULTURAL NATIONAL-LEVEL INDICATORS}

Population (millions)

Urban population (\%)

Media (Old and New)

\section{ECONOMIC NATIONAL-LEVEL INDICATORS}

GDP per capita

Real GDP Growth

Unemployment rate

Income inequality (Gini rank)
SOURCE: OECDstatistics

Urban population refers to people living in urban areas as defined by national statistical offices. SOURCE: OECDstatistics

The UIS is developing a new survey on print, broadcast and digital media which is being pilot tested in a growing number of countries on a yearly basis. This survey focuses on key issues, such as changes in the number of radio and TV channels and newspapers, the concentration of media ownership, and the rise of digital news outlets. Source: Media Statistics Country Profiles (Pilot Survev)

Is the market value of all officially recognized final goods and services produced within a country in a given period of time. GDP per capita is often considered an indicator of a country's. SOURCE: OECDstatistics

An inflation-adjusted measure that reflects the value of all goods and services An inflation-adjusted measure that reflects the value of all goods and services "constant-price", "inflation-corrected" GDP or "constant dollar GDP". SouRCE: "constant-price",

Percentage of total workforce, who is unemployed and is looking for a paid job. Unemployment rate is one of the most closely watched statistics because a rising rate is seen as a sign of weakening economy that may call for cut in rising rate is seen as a sign of weakening economy that may call for cut in
interest rate. A falling rate, similarly, indicates a growing economy, which is interest rate. A falling rate, similarly, indicates a growing economy, which is
usually accompanied by higher inflation rate and may call for increase in interest rates. SOURCE: OECDstatistics

A measurement of the income distribution of a country's residents. This number, which ranges between 0 and 1 and is based on residents' net income, helps define the gap between the rich and the poor, with 0 representing perfect equality and 1 representing perfect inequality. SOURCE: OECDstatistics 